\title{
VIETNAM SOLAR
}

COMPETITIVE BIDDING

STRATEGY AND FRAMEWORK

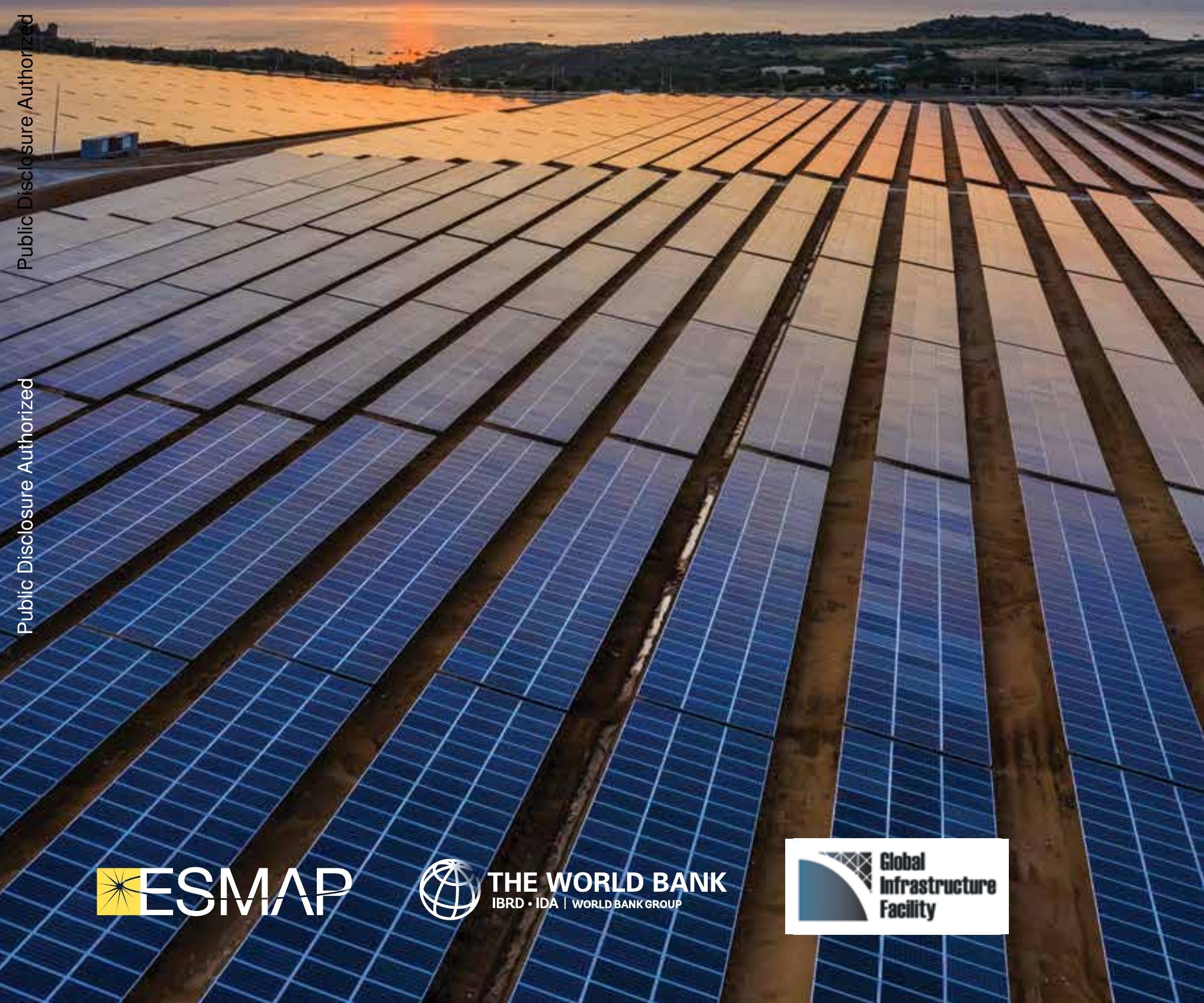


This report was researched and prepared by the World Bank with the contributions of its consultants PricewaterhouseCoopers (PWC) and Baker McKenzie. The work was funded by the Energy Sector Management Assistance Program (ESMAP), a multi-donor trust funded program administered by the World Bank, and the Global Infrastructure Facility (GIF).

Authors: World Bank Group (Sabine Cornieti and Ky Hong Tran with the support of Agnes Chew, Franz Gerner, Rahul Kitchlu, Bhanu Mehrotra, Cam Thi Kim Nguyen and Edwin Hin Lung Yuen) with the contributions from PWC (Raamkumar M Ragu, Rahul Raizada, Glenn Hughes, Kameswara Rao, Nikhil Abraham, Tran Nhat Bach, Abhinav Goyal) and Baker McKenzie (Chi Lieu Dang and Thanh Hai Nguyen).

Peer-reviewers: Arnaud Braud, Claire Nicolas and Nadia Taobane (World Bank)

Editor: Stephen Spector and Steven Kennedy

Design: Debra Naylor, Naylor Design, Inc

( 2019 International Bank for Reconstruction and Development / The World Bank

1818 H Street NW | Washington DC 20433

202-473-1000 | www.worldbank.org

This work is a product of the staff of the World Bank with external contributions. The findings, interpretations, and conclusions expressed in this work do not necessarily reflect the views of the World Bank, its Board of Executive Directors, or the governments they represent.

The World Bank does not guarantee the accuracy of the data included in this work. The boundaries, colors, denominations, and other information shown on any map in this work do not imply any judgment on the part of the World Bank concerning the legal status of any territory or the endorsement or acceptance of such boundaries.

\section{Rights and Permissions}

The material in this work is subject to copyright. Because the World Bank encourages dissemination of its knowledge, this work may be reproduced, in whole or in part, for noncommercial purposes as long as full attribution to this work is given.

Any queries on rights and licenses, including subsidiary rights, should be addressed to: World Bank Publications, World Bank Group, 1818 H Street NW, Washington, DC 20433, USA; fax: 202-522-2625; pubrights@worldbank.org.

ESMAP and the GIF would appreciate a copy of or link to any publication that uses this publication as a source, addressed to ESMAP Manager/GIF Manager, World Bank, 1818 H Street NW, Washington, DC, 20433 USA; esmap@worldbank.org/managementunit@globalinfrafacility.org.

All images remain the sole property of their source and may not be used for any purpose without written permission from the source.

\section{Attribution}

Please cite the work as follows: "World Bank. 2019. Vietnam Solar Competitive Bidding Strategy and Framework. Washington, DC: World Bank." 


\section{VIETNAM SOLAR COMPETITIVE BIDDING STRATEGY AND FRAMEWORK}





\section{CONTENTS}

$\begin{array}{lr}\text { Executive Summary } & 5\end{array}$

$\begin{array}{lr}\text { 1. Introduction } & 9\end{array}$

2. Solar Deployment Targets and Timeline 11

3. Legal Framework $\quad 13$

3.1 Review of Legal Framework Possibilities 13

3.1.1 MOIT to develop further guidance on bidding procedures $\quad 13$

$\begin{array}{ll}3.1 .2 & \text { Investment law }\end{array}$

3.1.3 Bidding legal framework for selection of contractor to provide goods and services 13

3.1.4 Bidding legal framework for selection of investors for projects using land $\quad 14$

$\begin{array}{ll}\text { 3.1.5 Public-Private-Partnership (PPP) law } & 14\end{array}$

3.2 Legal Recommendations 14

4. Deployment Scheme $\quad 16$

$\begin{array}{ll}4.1 \text { Substation Based Competitive Bidding } & 17\end{array}$

$\begin{array}{ll}\text { 4.1.1 Description of the bidding model } & 17\end{array}$

$\begin{array}{ll}\text { 4.1.2 Key steps for substation-based bidding scheme } & 17\end{array}$

$\begin{array}{ll}4.1 .3 \text { Technical aspects } & 18\end{array}$

$\begin{array}{ll}\text { 4.1.4 Permits } & 18\end{array}$

4.2 Solar Park Competitive Bidding $\quad 18$

$\begin{array}{ll}\text { 4.2.1 Description of the bidding model } & 18\end{array}$

$\begin{array}{ll}4.2 .2 \text { Key steps for solar parks } & 20\end{array}$

$\begin{array}{ll}4.2 .3 \text { Permits } & 20\end{array}$

5. Roles and Responsibilities $\quad 21$

5.1 Substation-Based Roles and Responsibilities $\quad 21$

5.2 Solar Park Competitive Bidding Roles and Responsibilities 21

6. Bidding Framework $\quad 22$

$\begin{array}{ll}6.1 \text { Bidding Mechanism } & 22\end{array}$

6.2 Procurement Framework $\quad 23$

$\begin{array}{ll}6.3 \text { Contractual Framework } & 23\end{array}$

\begin{tabular}{ll}
7. & Socio-Economic Benefits Strategy \\
\hline 8. & 24
\end{tabular}

$\begin{array}{ll}\text { 8. Conclusion } & 27\end{array}$

Annex 1. The Vietnam Power Sector Reform Program $\quad 31$

Annex 2. Results of Geospatial Analysis $\quad 34$

$\begin{array}{lr}\text { Annex 3. PV Supply Chain Analysis } & 38\end{array}$ 


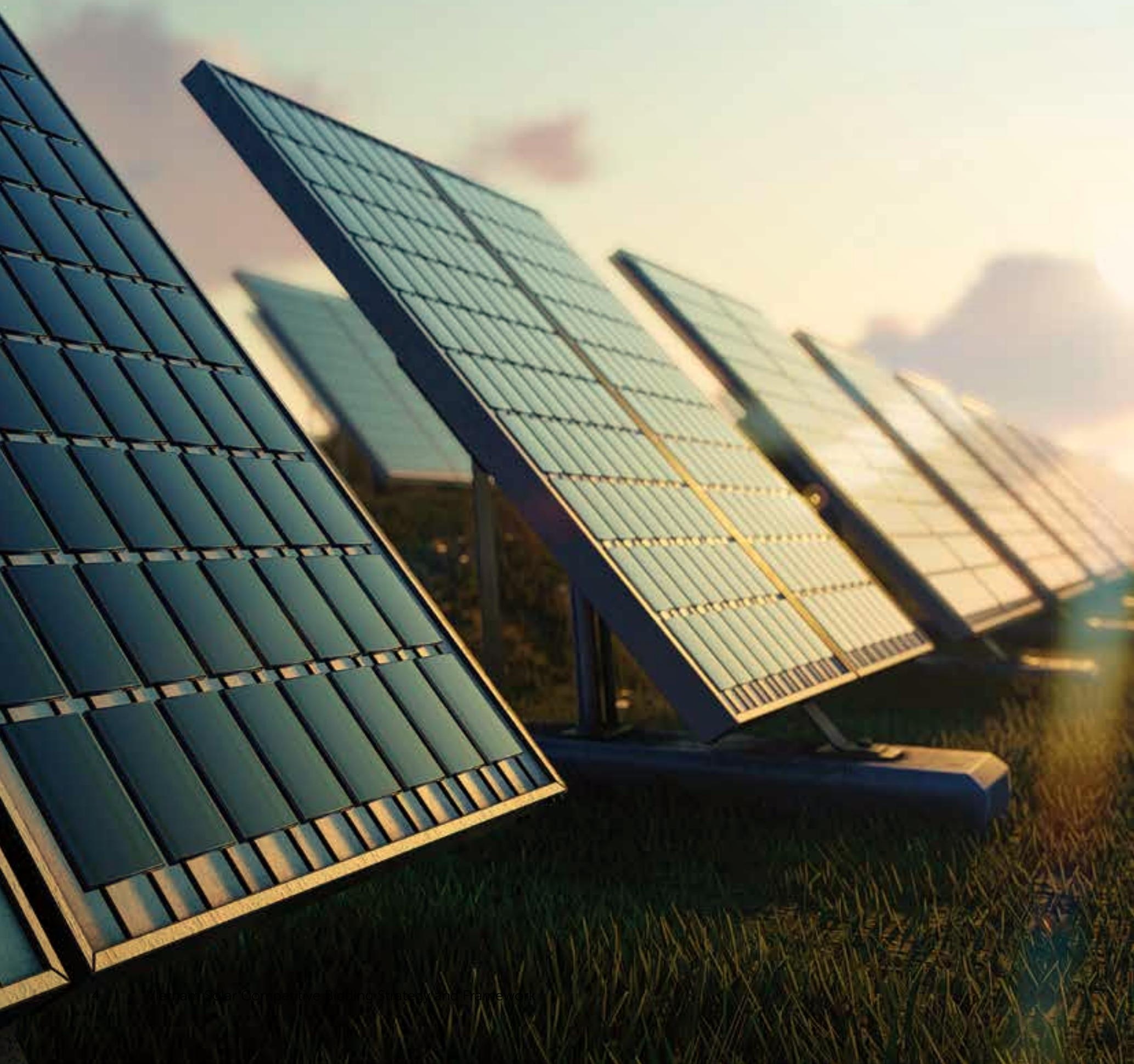




\section{EXECUTIVE SUMMARY}

\section{BACKGROUND}

Solar power generation is an increasingly attractive option for Vietnam thanks to recent cost reductions, fast construction timelines, and the contribution solar power can make to ensuring energy security and environmental sustainability.

In March 2016, Vietnam's Prime Minister approved, in Decision 428/QD-TTg, proposed revisions by the Ministry of Industry and Trade (MOIT) to the National Power Development Plan VII (Revised PDP 7) for the period 2016-2020 with a vision to 2030. Under the plan, the total installed generation capacity was expected to rise to 60 gigawatts (GW) in 2020 , to $96 \mathrm{GW}$ in 2025, and $130 \mathrm{GW}$ in 2030. The current installed capacity is around $47 \mathrm{GW}$. Therefore, the 60 GW by 2020 target will not be met - mostly due to a lower electricity demand growth than expected that reduced the need for more installed generation.

The Revised PDP 7 places greater emphasis on renewable energy development and outlines its strategy for expanding renewable energy generation. The plan sets a target of 6.5 percent of installed generation from renewable sources (excluding large-scale hydropower) by 2020 and 10.7 percent by 2030. It also sets a target of 850 megawatt (MW) of installed solar photovoltaic (PV) capacity in 2020, 4 GW by 2025, and $12 \mathrm{GW}$ by 2030

To support the development of solar PV, the Government of Vietnam, in April 2017, issued Decision 11/2017/QD-TTg, which established a feed-in-tariff (FIT). The FIT policy expired in June 2019. The policy laid out how independent power producers (IPPs) could apply for the FIT. It set a tariff of VND 2,086 per kWh (set at US\$ 0.0935 per kWh) for 20-year power purchase agreements (PPAs). A second phase of the FIT (FIT 2 ) is currently under discussion for projects that would reach commercial operation date (COD) by end 2020. Around 4.5 GW of solar generation was deployed under the FIT before mid-2019, meeting the 2025 PV targets in 2019.

The Government of Vietnam is revisiting its solar targets under the Power Development Plan 8 for the period 20212030 (PDP 8). The current target under discussion for solar generation is $18 \mathrm{GW}$ by 2030 . PDP 8 is expected to be finalized and published early 2020.

\section{SOLAR COMPETITIVE BIDDING PROGRAM FOR VIETNAM}

Aiming to scale up solar generation in a sustainable and affordable manner, the Government of Vietnam plans to shift from the FIT to a competitive bidding mechanism. With the support of the World Bank, the Government of Vietnam is designing the program based on the present strategy developed with input from several ministries, the private sector, and development partners. The strategy presents recommendations to the Government of Vietnam aiming to provide a clear path to develop a sustainable solar program.

As part of a carefully designed strategy, decisions must be made in the following areas: (i) the roles and responsibilities of the various public and private parties, (ii) whether changes need to be made to the existing laws and regulations, (iii) the types of deployment schemes that are best suited to Vietnam's circumstances, and (iv) what risks the Government of Vietnam will internalize and what mitigation instruments it might offer IPPs. The clarification of these points prior to the selection of an IPP will help speed up the IPP selection process, reduce the chances of procurement failure, and provide a long-term vision for deploying solar projects. From the IPPs' perspective, a clear government 
strategy reduces perceived risks related to a weak or inadequate legal framework, unclear selection process, or other development concerns.

The main points of the strategy are presented below.

- Solar Deployment Targets and Timeline. To signal to private investors that Vietnam represents a long-term potential investment in the global solar market, it is critical to have medium-term solar deployment targets with clear timelines. As PDP 8 has not yet been finalized, this report assumes a revised target of $18 \mathrm{GW}$ solar by 2030 . The 18 GW is not an official target and therefore, it is merely being used as an illustration.

The current status of solar deployment built under the FIT 1 policy, which expired in June 2019, is approximately $4.5 \mathrm{GW}$. Based on the new projects coming online and the announcement of the FIT 2 specificities, the report assumes another $1.5 \mathrm{GW}$ to be developed by the end of 2020 . Together, this represents around $6 \mathrm{GW}$ of solar PV projects to be built under the FIT policy. Therefore, $12 \mathrm{GW}$ will be expected to be built under competitive bidding by 2030 .

Vietnam could pilot competitive bidding in 2020/2021 through three different schemes totaling $1.2 \mathrm{GW}$ : (i) 500 MW substation-based competitive bidding; (ii) $200 \mathrm{MW}$ floating solar parks; and (iii) $500 \mathrm{MW}$ ground-mounted solar parks. After the pilot phase, 1-2 GW of capacity should be installed every year using a mix of substation-based bids and solar parks (further indications are provided in Section 2 on the timeline and in Section 4 on deployment schemes). International experiences suggest that tenders should be held in a regular manner, such as every 12 or 18 months, in accordance with PDP 8's nominated capacity.

- Legal Framework. The current regulations in Vietnam do not explicitly provide a comprehensive framework for competitive selection of IPPs in the Vietnamese energy market. Therefore, the Government of Vietnam will have to provide additional legal guidance to the existing law. However, as the IPP competitive bidding selection in the energy market can technically be hosted under different regulations, such as the public-private-partnership (PPP) law, the investment law and the bidding law, or under MOIT's framework, a decision must be taken under which law/regulation the competitive selection will be hosted.

Based on a full legal review and extensive discussions with the Ministry of Planning and Investment (MPI), MOIT, and other ministries, the investment law is recommended. Hosting competitive bidding under the investment law will ensure coordination between the national generation master plan and provincial investment plans, linking the selection of IPPs with the granting of the investment license. Its implementation will require strong coordination between national and provincial agencies.
A Prime Minister's Decision will be needed to provide guidance on two fronts. First, cooperation among MOIT, Electricity Vietnam (EVN), and the local authorities (Provincial People's Committees (PPCs) and Departments of Planning and Investments (DPIs)) related to the bidding process, particularly the criteria and procedures to be used in the evaluation and selection processes. The roles and responsibilities of each entity will need to be described. Second, on the selected deployment schemes and the high-level bidding framework (i.e., payment mechanism, tariff structure, the term of PPAs, and potential government support).

To ensure that the inclusion of projects into the PDP does not become a bottleneck, the Government of Vietnam needs to create some flexibility over project allocation in the PDP. It would be optimal to allow unallocated solar capacity in the PDP, that is, to not allocate a given quantity of capacity to a specific project and instead mention that it is a capacity reserved for the winning IPP/project under the competitive selection. This sort of flexibility is quite common. With the move from publicly owned generation to privately owned, the Government of Vietnam setting the optimal mix through a process of evidence-based planning is becoming more critical. The Government of Vietnam should determine the medium-term energy mix in the PDP 8 and select investors based on the optimal timing for power plants to come online.

- Deployment Schemes. After a thorough review of the various competitive schemes used internationally and the key challenges Vietnam is facing, two deployment schemes are recommended: (i) substation-based competitive bidding and (ii) solar park competitive bidding (ground-mounted and floating).

These schemes seek to address the key constraints faced in Vietnam, namely grid availability, risk of curtailment, and complex land allocation. Both schemes aim to reduce the development risks perceived by IPPs, thus reducing the risk premium in the cost of capital. The main outcome expected is a reduced PPA tariff proposed by developers compared to a location agnostic competitive bidding.

Under substation-based competitive bidding, it is important to ensure that when selecting the substations, a screening of environmental and social constraints for land around the substation is completed in coordination with the provinces. The IPPs select the land themselves, complying with national environmental and social regulations.

Under the solar park competitive bidding, the government selects the land and does so in coordination with the provinces to ensure minimal environmental and social impact.

- Roles and Responsibilities. The key public actors involved in the selection of IPPs through competitive bidding are MOIT, MPI, EVN, and the PPCs in which the substation/ 
TABLE ES.1. Roles and responsibilities

\begin{tabular}{|c|c|c|}
\hline ROLE & RESPONSIBILITY & STAKEHOLDER(S) \\
\hline $\begin{array}{l}\text { Bidding selection } \\
\text { committee }\end{array}$ & $\begin{array}{l}\text { The committee (i) develops with the transaction advisors the } \\
\text { bidding documentation and framework; and (ii) launches, } \\
\text { implements, and concludes the IPP selection process. }\end{array}$ & $\begin{array}{l}\text { MOIT and/or EVN leads the process with } \\
\text { the support of EVN/MOIT and the PPC for } \\
\text { the area in which each substation/solar } \\
\text { park is located. PPCs must be fully involved, } \\
\text { as the selection process leads to the } \\
\text { approval of the investment license (directly } \\
\text { or indirectly depending under which law } \\
\text { the competitive bidding is hosted). }\end{array}$ \\
\hline PPA signatory & $\begin{array}{l}\text { The PPA signatory signs the PPA with the IPP and pays for } \\
\text { the electricity provided by the IPP at the price determined } \\
\text { through competitive bidding. }\end{array}$ & $\begin{array}{l}\text { EVN, but this could change after the } \\
\text { electricity market is fully in place; see } \\
\text { Annex } 1 .\end{array}$ \\
\hline $\begin{array}{l}\text { Selection of substations/ } \\
\text { feeders and their capacity }\end{array}$ & $\begin{array}{l}\text { Substations and feeders are selected as part of a larger } \\
\text { technical study of the grid so as to ensure minimal VRE } \\
\text { integration constraints and that suitable land is available } \\
\text { around the substation. }\end{array}$ & $\begin{array}{l}\text { EVN/NPT/Power Corporations (PCs), with } \\
\text { the support of PPC and MOIT. }\end{array}$ \\
\hline Solar park land selection & $\begin{array}{l}\text { The land selection must be aligned with the Province land } \\
\text { master plan and with the goal of minimizing environmental } \\
\text { and social impacts. }\end{array}$ & PPC with the support of MOIT and EVN \\
\hline $\begin{array}{l}\text { Land clearing for } \\
\text { solar park }\end{array}$ & $\begin{array}{l}\text { People on the selected land are compensated, and full } \\
\text { ownership is transferred to the stakeholder. }\end{array}$ & PPC or EVN \\
\hline Solar park agency & $\begin{array}{l}\text { Technical development, financing, and construction of the } \\
\text { infrastructure (fence and transmission line) and operation } \\
\text { and maintenance (O\&M). }\end{array}$ & Public entity (PPC or EVN) \\
\hline Power plant owner & $\begin{array}{l}\text { The plant owner is responsible for (i) financing, building, } \\
\text { and operating the solar power plant; and in the case of } \\
\text { substation-based competitive bidding: (ii) identifying land; } \\
\text { and (iii) paying resettlement compensation. }\end{array}$ & IPP selected under the competitive bidding \\
\hline
\end{tabular}

solar park is located. The main roles and responsibilities are set forth in table ES.1.

- Bidding Framework. The bidding framework provides the framework for procurement of the entire solar program. It encompasses (i) procurement issues, and (ii) contractual issues. Specifically, it includes details of the bidding mechanisms, procurement framework, and contractual arrangements that are to form the basis for the contracts between the government and the winning IPP. Each of these parameters enables a sustainable and scalable bidding program by balancing risk among stakeholders during the bidding process and over the life of asset.

The core recommendations under the high-level bidding framework are:

\section{a. Bidding mechanisms}

- Bidding process. A request for qualification (RFQ)/ request for proposal (RFP) two-envelope process is recommended for the pilot competitive bidding in Vietnam

- Qualification criteria. To ensure participation of established IPPs in the bidding process, the bidding process shall test the IPPs for both technical capabilities and financial capabilities. Technical capabilities shall include proven experience of IPPs in development/construction of projects of similar capacity. Financial capabilities shall test the ability of IPPs to obtain long-term financing and equity.

- Iterative price discovery mechanism. An iterative bidding process typically occurs in real time via the internet. It can achieve greater price reductions than those to be had through a static, paper-based process. However, such a system requires market maturity, preparation, and competition if it is to yield positive results. Hence, for the initial pilot bidding a sealed envelope financial bid is recommended.

- Winner selection. Because the Government of Vietnam's current focus for the solar industry is to attract the most cost-effective technology and funding, it is recommended that winners be selected based on the lowest tariff submitted.

\section{b. Procurement framework}

- Payment mechanism. Energy-based payments, i.e. net metered energy exported by the solar project in $\mathrm{MWh} / \mathrm{kWh}$, are recommended for the tariff quoted by the IPP in a solar bid, instead of a MW-based payment mechanism.

- Tariff structure. In the short-term, the tariff structure can be fully indexed to U.S. dollars and infla- 
tion. The medium-term goal should be only partial indexation to U.S. dollars or full payments in Vietnam Dong (VND), depending on the state of the domestic lending market at the time of the competitive bidding.

- Ceiling tariff. For the pilot competitive bidding, the FIT can be used as the ceiling tariff to ensure that the competitive bid will be lower than the FIT.

\section{c. Contractual framework}

- PPA term. Considering the asset life of solar power plants and that they are capital-intensive, a PPA term of 25 years is recommended for projects under the bidding scheme.

- Off-take arrangement. Provision for deemed generation beyond a specified number of hours is recommended in the PPA. In a competitive bidding scenario reduction of such curtailment risks in solar projects enables reduction in tariff as developers would have otherwise priced it in their bids.

- Change in law. Considering changing regulatory dynamics in Vietnam such as the introduction of the Vietnam wholesale electricity market (VWEM), it is recommended that the IPP is protected from any change in law by a letter of support from the Government of Vietnam.

- Termination and arbitration. It is recommended that provisions for termination due to seller event of default and procurer event of default should be available in PPA, along with commensurate termination compensation mechanism and international arbitration

\section{- Socio-Economic Benefits Strategy}

Based on a supply chain analysis conducted in 2018 and described in Annex 3, the 12 GW PV target from the Revised PDP 7 is expected to support as many as 25,000 full-time jobs in project development, services, and O\&M annually through 2030. Solar PV-related employment in Vietnam will derive from (i) development and operation of solar PV power plants, and (ii) manufacturing of equipment. The first category comprises jobs in development, design, construction, and commissioning of solar PV plants. Job creation in manufacturing is expected to reach nearly 20,000 full-time equivalents by 2030 . Most of these jobs will be export-driven and depend on Vietnam maintaining its current share of the global solar PV market. That, in turn, will depend on the country retaining its attractiveness to international solar PV manufacturers.

As per the results of this supply chain analysis, the new solar program can be a catalyst for socio-economic benefits and can be supported in the following ways.

a. Provide visibility locally and internationally. To support the development of local industry, the Government of Vietnam can (i) inform the market of the programs' features, including local and industrial development targets, and (ii) take local suppliers through the solar value chain to allow them to identify relevant opportunities so they can position themselves as needed.

b. Facilitate the assessment of local opportunities. The Government of Vietnam could conduct external studies to assess the potential of the local market in the solar value chain and share these studies with prequalified bidders to facilitate bidders' investigation of local opportunities to partner and subcontract.

c. Enhance the position of local players and local jobs on the value chain. The Government of Vietnam can map local players and their skills, then identify how they might fill gaps on the solar value chain.

When developing the solar parks, the Government of Vietnam can put an emphasis to ensure the population around the park become direct beneficiaries of the infrastructure. This can be provided through a yearly solar park fee that can be used for development projects or have compulsory hiring and training of local staff. Carrying out a socio-economic study to assess the needs of local communities would help in the design of tailor-made programs to meet these needs to the extent possible, in coordination with all the public stakeholders involved. A gender focus can also be promoted in these programs. 


\section{INTRODUCTION}

In its revised Power Development Plan 7 (revised PDP 7) published in 2016, the Government of Vietnam has set a goal of about 12 gigawatts (GW) of solar power. It set intermediary targets of installed solar generation of 850 megawatts (MW) in 2020 and $4 \mathrm{GW}$ in 2025. However, Vietnam had already reached its 2025 target by mid-2019, with over $4.5 \mathrm{GW}$ of installed solar capacity. The Government of Vietnam is now considering a higher target for solar generation in its new Power Development Plan 8 (PDP 8) from 12 to $18 \mathrm{GW}$. This increase is mostly linked to the fact that, under specific circumstances, solar photovoltaic (PV) generation could be the least-cost source of generation in Vietnam. PDP 8 is expected to be published in 2020 and will cover the period of 2020 to 2030.

The $4.5 \mathrm{GW}$ of solar projects built in Vietnam were developed under a feed-in-tariff (FIT) policy that expired mid-2019. The FIT power purchase agreement (PPA) tariff was US\$ 0.0935 per kWh for 20 years (FIT 1) as per the Decision 11 Circular issued by the Ministry of Industry and Trade (MOIT). A draft new Decision is under discussion (FIT 2). In November 2019, the Prime Minister requested MOIT to (i) consider applying a revised FIT price to the projects that meet certain conditions including having signed PPAs and reaching commercial operation date (COD) by end-2020, and (ii) develop a competitive, open and transparent bidding mechanism to reduce the cost of solar generation.

Since 2018, the World Bank has been supporting the Government of Vietnam in its transition from FIT to competitive bidding. The main constraints identified in a sustainable and affordable deployment of solar PV in Vietnam are described below. a. Lack of centralized controlled planning creates evacuation constraints and generation curtailment. There was no clear link between the revised PDP 7 and the solar master plan. The latter had a much higher volume of solar than what was proposed under the revised PDP 7. The transmission plan is also not coordinated with the volume presented in the Solar Master Plan leading to further variable renewable energy (VRE) integration constraints. Moreover, under the FIT, the independent power producers (IPP) decide where the solar projects are located and prepare a grid integration study to be approved by Electricity Vietnam (EVN). Therefore, as EVN does not know which ones will reach COD, it evaluates projects individually, one project after the other, without being able to assess them together as a whole. This challenge led to an unexpected construction of $4.5 \mathrm{GW}$ of solar generation, five times more than what was planned under revised PDP 7. These projects are now facing important curtailment and brought shortfall in transmission capacity planned by EVN.

b. Lack of clear and agreed upon parameters to evaluate the quality of the projects. There was no cap on solar capacity to be developed in each province and there were no agreed upon parameters between provinces to evaluate the quality of the IPP solar proposals. Therefore, as the proposals received exceeded the target capacity set in the Revised PDP 7, it was a non-harmonized process between provinces to select the ones that should be added in the Solar Master Plan and get their required investment license. 
c. Land availability and planning challenges. Because Vietnam is a fertile country of tropical lowlands, hills, and densely forested highlands, with level land covering no more than twenty percent of its geography, there are competing demands for land that impact solar PV deployment. Land usage is presented in the land master plan led by the provinces. Currently, the land master plan is not synchronized with the generation master plan. As the deployment of solar is land intensive, land availability and land planning are challenging when developing solar generation.

d. Numerous actors with different responsibilities that are interlinked. There are key national level actors such as MOIT, the Ministry of Planning and Investment (MPI), the Ministry of Natural Resources and Environment (MONRE) and EVN; at the province level there are the Department of Planning and Investment (DPI), the Department of Industry and Trade (DOIT), the Department of Natural Resources and Environment (DONRE), and the Provincial's Party Committee (PPCs). For a smooth planning process, it is key for the stakeholders to have clear responsibilities and roles while working together.

e. Lack of available non-recourse project financing in Vietnam Dong. The current PPA terms reduces the possibility of IPPs to access USD project financing. Local banks are comfortable with the PPA and EVN's risks and are willing to finance the solar PV projects. However, currently no local bank can finance solar PV projects under a nonrecourse project-financing scheme and provide longer tenors, which in turn limits the interest among IPPS, as well as the number of IPPs that can develop projects without a strong balance sheet or group support.

The present report outlines the framework for a Vietnamese Solar Competitive Bidding Program with the intention of scaling up the deployment of solar at competitive electricity purchase tariffs. The proposed recommendations answer the above identified constraints to ensure the sustainability and successful deployment of the Program. The strategy presents recommendations to the Government of Vietnam aiming to provide a clear path to develop a sustainable solar program.

In particular, Section 2 presents solar deployment targets and timeline based on international best practices. Section 3 outlines the changes in the legal framework that are required to ensure a smooth implementation of competitive selection of IPPs. Section 4 presents the two deployment schemes recommended in Vietnam when assessing its grid and land constraints. Section 5 further presents the roles and responsibilities of the key actors based on the legal framework proposed and the recommended deployment schemes. Section 6 outlines the bidding mechanisms, procurement framework and contractual framework recommended, and Section 7 presents recommendations with regards to increasing socio-economic benefits.

The Solar Competitive Bidding Program endorsed by the Government of Vietnam will need to integrate all these aspects to ensure that solar deployment becomes a catalyst for socio-economic development while keeping electricity prices low to not impede economic development. 


\section{SOLAR DEPLOYMENT TARGETS AND TIMELINE}

To signal to private investors that Vietnam is a reliable longterm potential investment in the solar market, it is critical to have medium-term deployment targets with clear timelines (every 12,18 , or 24 months) that can be communicated to the private sector.

As the new PDP 8 is not finalized, based on discussions with MOIT, this report assumes an $18 \mathrm{GW}$ solar target by 2030 . The $18 \mathrm{GW}$ is not an official target and therefore, it is merely being used as an illustration. By mid-2019, the status of solar deployment built under the FIT 1 policy was around $4.5 \mathrm{GW}$. Another $1.5 \mathrm{GW}$ is expected to be developed under FIT 2 by end 2020. Therefore, in total around 6 GW are assumed in the present report to be built under the FIT policy. As per the Government of Vietnam's decision to move from FIT to competitive bidding, the $12 \mathrm{GW}$ left will be built under competitive bidding by 2030 .
Based on international experiences, launching bids in a regular manner such as every 12 or 18 months is recommended, following the targets approved in the generation plan. This process may need to be adapted to the new electricity market under which EVN may not be the sole buyer (see Annex 1). However, it is important to note that as solar projects are capital expenditure (CAPEX) intensive it requires long-term PPAs, for IPPs to be able to access long-term debt under project financing and reduce their PPA price.

As described further in Section 4, the Government of Vietnam can pilot competitive bidding in 2020/2021 through three different schemes: (i) substation-based competitive bidding, (ii) floating solar park and (iii) ground-mounted solar parks. These will enable the Government of Vietnam to pilot two different deployment schemes, substation-based com-

\section{FIGURE 2.1. Solar deployment (GW) per year of COD}

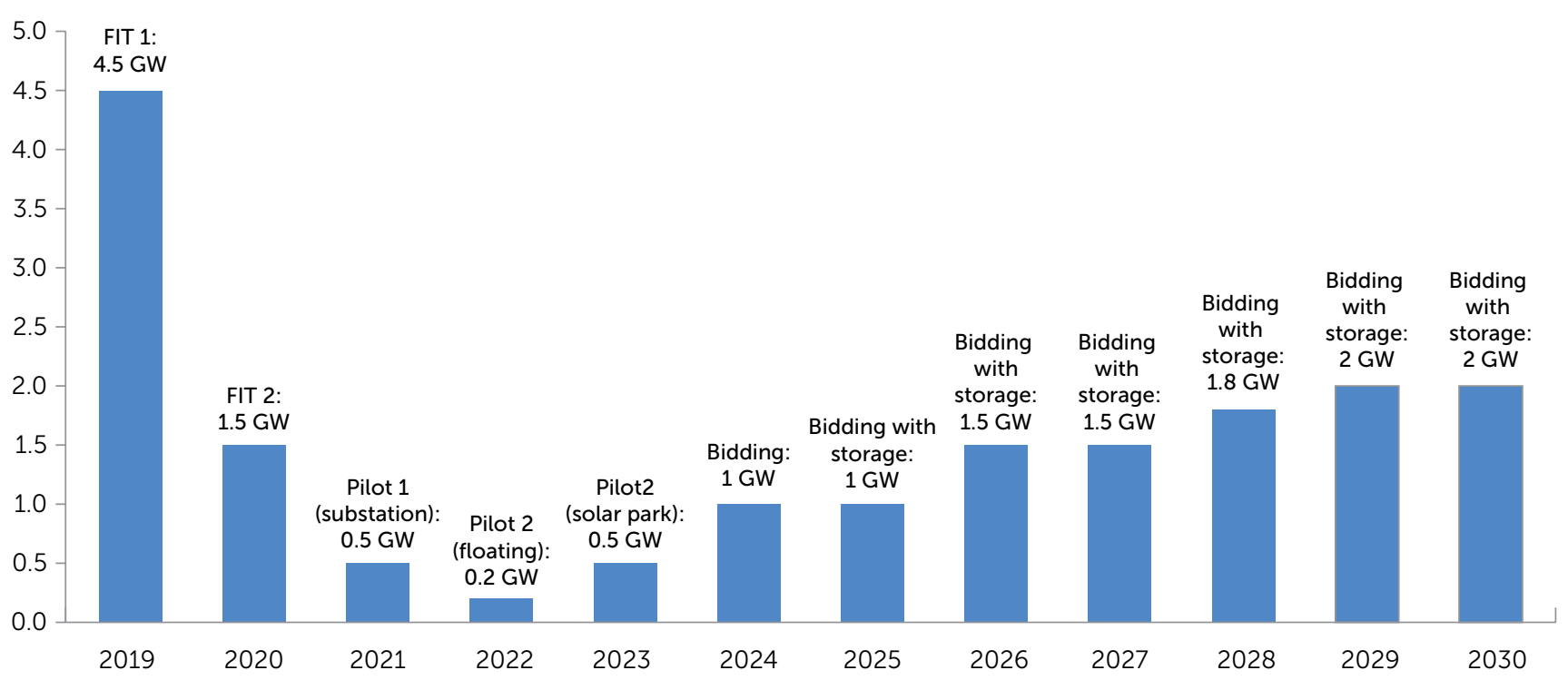


petitive biding and solar parks that have different advantages and limitations and are quite commonly developed in parallel in large solar generating countries such as India. The two schemes are presented in Section 4. This pilot plan will also enable the Government of Vietnam to try two different types of technology, namely floating PV and ground-mounted PV. These also have different advantages and limitations. Floating PV can be collocated with hydro generation which decreases its potential impact on the grid and reduces the impact on land but is limited since it needs a large enough body of water to host the plant. Ground-mounted is more flexible in where it can be located and be timely developed at scale but requires a large amount of free land.

After the pilot phase, the Government of Vietnam may want to launch around 1-2 GW a year with a mix of substation-based bids and solar parks. After 2025, when battery storage prices are expected to have dropped by another 20-30 percent from today's levels, it is recommended to launch tenders of solar PV with battery storage to improve the integration of solar generation in the grid from a least-cost perspective. Figure 2.1 is an illustration of what could be proposed under the solar program. However, it is important to link these targets to a comprehensive least-cost generation plan that is to be approved under PDP 8.

This process will require an estimated six months, from the launch of the competitive bid with the request for qualification (RFQ), to the request for proposals (RFP) and PPA signature. Under substation-based competitive bidding, the IPP will need to also acquire the land and finalize the environmental and social studies prior to financial close. Therefore, under substation-based competitive bidding after IPP selection, around 12-18 months are assumed before commercial operation date (COD). Under the solar park scheme, the Government of Vietnam will need to identify the land and acquire selected permits prior to the selection of the winning IPP. However, this time is regained after PPA signature as the IPP does not need to do those steps and usually COD is reached within 12 months after IPP selection under the solar park scheme. 


\section{LEGAL FRAMEWORK}

The current regulations in Vietnam do not specifically provide the framework for competitive selection of IPP in the energy market. Therefore, the Government of Vietnam needs to provide additional legal guidance to the existing law. The competitive selection of IPPs could be hosted under different regulations, namely the investment law, the bidding law and the PPP law. Alternatively, the Prime Minister could issue a Decision to host the competitive selection under the current MOIT framework and provide further guidance to MOIT on competitive bidding.

Based on a full legal review and the type of deployment schemes recommended for Vietnam, and extensive discussions with MPI, MOIT and other ministries, the investment law may be the most appropriate. It ensures coordination between the generation master plan and the province investment plan, linking the selection of the IPP with the granting of the license. However, its implementation will require strong coordination between the national and provincial agencies and a good alternative is the MOIT guidance.

\subsection{REVIEW OF LEGAL FRAMEWORK POSSIBILITIES}

The following options for can be considered from a legal perspective to deploy competitive bidding:

\subsubsection{MOIT to develop further guidance on bidding procedures}

Under this option, MOIT issues a circular on competitive bidding procedures for solar projects under the current regulation. In that case, the competitive bidding procedures are conducted separately from the PDP inclusion procedures and investment license approval procedures. After being selected from competitive bidding process, IPPs are responsible for obtaining approval for the investment license.
To provide legal basis for issuance of the MOIT's circular, the Prime Minister needs to issue a Decision to assign MOIT to issue the circular presenting guidance on implementing the competitive bidding procedures for solar power projects.

\subsubsection{Investment law}

The investment law provides procedures for the assessment and approval of investor-proposed projects. However, a bidding procedure (i.e., bidding among several projects proposed by several investors) is not yet available under the investment law. To host the solar competitive bidding under the investment law will require the Government of Vietnam to issue a legal document to guide/detail the investment law concerning competitive bidding process.

Under this option, the competitive bidding procedures for PPA signature are incorporated with the investment license approval procedures. This means that, as a result of the competitive bidding process, selected projects are granted the investment license under the Investment Policy Decision and will sign the PPA.

This option is more suitable for competitive bidding among newly proposed projects that have not been issued with approval for inclusion in the PDP and were granted an investment license.

\subsubsection{Bidding legal framework for selection of contractor to provide goods and services}

The bidding regulation provides for specific bidding procedures (i.e., selection criteria, RFP templates) for goods procurement or services bidding packages. However, with the current bidding regulation, selection of electricity suppliers may not be considered under procurement of goods, services, or any other activities that are subject to the bidding regulations. To host the competitive selection under 
the bidding regulation 63/2014 will require the Government of Vietnam to amend the bidding regulations (bidding law, Decree No. 63/2014/ND-CP, and guiding circulars) to accommodate the solar competitive bidding program.

It is proposed that under this option, the bidding process is separated from the development right, since after the competitive bidding process, selected IPPs are responsible for obtaining the remaining licenses and approvals for their projects. Therefore, this option would be preferred for solar projects that have already been issued with relevant investment and development permits and licenses.

\subsubsection{Bidding legal framework for selection of investors for projects using land}

This legal framework was designed for projects using land with high-commercial value, whereas solar power projects are normally developed in unpopulated areas. This causes several gaps when applying the existing bidding mechanism to this option. To host the competitive selection under the bidding regulation 30/2015 and 16/2016 will require the Government of Vietnam to amend existing regulations (bidding law, Decree No. 30/2015/ND-CP, and Circular No. $16 / 2016 /$ TT-BKHDT) to accommodate the gaps.

\subsubsection{Public-Private-Partnership (PPP) law}

In May 2018, the Government of Vietnam issued Decree No. $63 / 2018 / N D-C P$, which at the moment serves as the main legal basis for investment activities in the form of PPP. Article 4.1 of Decree 63 encourages the implementation of investment project under the PPP form, especially for the following sectors: transport; power plants, transmission lines, public lighting system, infrastructure works for commerce, urban areas, economic zones, industrial parks, industrial complexes, agriculture and rural development, etc.

Theoretically speaking, it would be possible to apply the PPP regulations to solar projects, especially for large-scale projects. However, as a matter of practice, PPPs are not a common investment form for solar or other renewable power projects in Vietnam (compared to the IPP / private investment form). PPP regulations only work for projects that have been identified. Regardless of whether projects are proposed by government authorities or investors, Decree 63 ultimately aims at finding an investor to develop a particular investment project, which would be done via a bidding process. This would not be possible for substation-based competitive bidding. However, it would be possible to develop the solar parks under the PPP legal framework for power projects (including Circular No. 38/2015/TT-BCT of the MOIT guiding on PPP investment for power projects).

\subsection{LEGAL RECOMMENDATIONS}

Both the PPP law and the bidding law present limitations to either one of the selected competitive bidding schemes, namely substation-based competitive bidding and solar parks. The simpler option is the MOIT guidance, but the most comprehensive option that may lead to lower PPA price is the investment law.

Under the investment law option, the Prime Minister must issue a Decision outlining the following:

a. Hosting of the competitive bidding under the investment law. By doing so, the Government of Vietnam guides the streamlining of the issuance of investment licenses for solar projects when an IPP signs a PPA under a competitive selection. After FIT 2 expires, provinces should be requested to relinquish any remaining investment licenses for solar projects to ensure fair competition between IPPs under competitive bidding.

b. Guidance on mechanisms for cooperation between the different agencies. The Government of Vietnam will need to provide guidance on mechanisms for cooperation between MOIT, EVN and the local authorities (PPCs and DPIs) for the bidding process. It will be critical to have strong cooperation in particular in evaluating and selecting projects as the end result of the competitive bidding will lead to the issuance of the investment license as well as the signature of the PPA which are led by the provinces and EVN/MOIT, respectively. Indeed, at the RFP stage after the IPPs are qualified, the IPPs would submit a technical proposal and a financial proposal that would enable them if selected to sign the PPA at their proposed price and be granted the investment license from the province. Therefore, MOIT with PPCs (as the investment approval authority) need to jointly receive the IPPs' bidding dossiers and conduct joint selections.

c. Guidance on roles and responsibilities of each stakeholder. The role and responsibilities of each agency under the two proposed competitive bidding schemes will need to be outlined clearly. The main stakeholders are MOIT, EVN, NPT, and PCC. They each have very strong roles to play in the success of the competitive bidding. Section 5 details the stakeholders' roles.

d. Provide flexibility over inclusion in PDP 8. To ensure that the inclusion of projects into the PDP does not become a bottleneck, Government of Vietnam needs to create some flexibility over project allocation in the PDP. It would be optimal to allow unallocated solar capacity in the PDP, that is, to not allocate a given quantity of capacity to a specific project and instead mention that it is a capacity reserved for the winning IPP/project under the competitive selection. 
e. Guidance on deployment scheme selected for the Program. Government of Vietnam needs to provide clear instruction to MOIT/EVN on the types of deployment scheme to be promoted in Vietnam. Substation-based competitive bidding and solar park (ground-mounted and floating) are recommended based on Vietnam's constraints. It is important that the schemes are nominated to be able to reflect the schemes' specific roles and responsibilities in the Decision. It would ensure smooth deployment of the Program. Moreover, it would provide legal ground for the development of solar parks and improve the coordination between the generation and land master plans. Deployment schemes are further presented in Section 4.

f. Guidance on high-level bidding framework. The main areas that need to be clarified by the Government prior to the launch of the competitive bidding are the qualification criteria, payment mechanism, the tariff structure, the PPA term and the government support. The investment law provides procedures for the assessment and approval of investor-proposed projects. However, a bidding procedure (i.e., bidding among several projects proposed by several investors) is not yet available under the investment law. A recommended high-level bidding framework is presented in Section 6. It's core recommendations are (i) selection of bidders after technical qualification is solely based on the criteria of price, with the project awarded to the bidder with the lowest price; (ii) the payment structure is in MWh or kWh not in MW; (iii) the tariff structure is to be indexed to inflation and in the short-term to foreign cur- rency, but with a medium-term vision to have partial indexation to U.S. dollars or full payments in Vietnam Dong (VND); (iv) the PPA term should be 25 years; (v) a letter of support from the Government of Vietnam in case of change in law to be attached to the PPA; and (vi) provide international arbitration.

The Prime Minister's Decision is only expected to provide a high-level indication on the medium-term Program. The precise bidding, contractual and procurement framework per phase is developed with the support of the transaction advisor and approved by the bidding selection committee, which encompasses MOIT, EVN and the provinces.

As an alternative, if the Government of Vietnam chooses the MOIT option, the Prime Minister could issue a Decision providing only the necessary instructions to MOIT to provide guidance on selection of IPPs. As mentioned, this option is less optimal than hosting the competitive bidding under the investment law as it may lead to higher PPA prices. Indeed, it would provide less comfort to IPPs: even if the IPP is selected under the competitive selection, it is not sure to be granted the investment license. A fast track process could be implemented under the substationbased competitive bidding so selected IPPs could acquire the investment license in a timely manner.

Under the Solar Park scheme, the investment license should be in any case automatically granted to the IPP as the project site would have been selected with the province and the government would have cleared the land for the solar park. 


\section{DEPLOYMENT SCHEME}

Based on the main identified risks in Vietnam, namely curtailment and complexity over land titling and potential discrepancies between the land master plan and the generation master plan, two deployment schemes are recommended: (i) substation-based competitive bidding and (ii) solar parks (floating and ground-mounted).

\section{TABLE 4.1. Development risks: land and grid}

\begin{tabular}{|l|l|}
\hline Land ownership risk & $\begin{array}{l}\text { Secured land rights are critical for long-term investment and financing. The main asset considered a security for } \\
\text { the lender is the solar plant. Its ownership relies on legal rights over the land, enabling the project company-the } \\
\text { special purpose vehicle (SPV) -to hold the plant during the project agreements (PPA and finance agreements). } \\
\text { Depending on the land's legal structure, access to land can be through formal, informal, or customary } \\
\text { systems. IPPs will assess the country's land tenure system to evaluate the land security the system provides to its } \\
\text { project. If land cannot be secured in a bankable manner, IPPs will usually not invest in the country or will have } \\
\text { expectations of very high equity returns. Solar parks are a good way to ensure ownership of the land to IPPs and } \\
\text { reduce risks over land availability. }\end{array}$ \\
\hline
\end{tabular}

\begin{tabular}{|l|l|}
\hline $\begin{array}{l}\text { Grid condition } \\
\text { knowledge and } \\
\text { curtailment risk }\end{array}$ & $\begin{array}{l}\text { Limited knowledge of grid availability/conditions leads to (i) the IPP spending excessive time trying to get informa- } \\
\text { tion from the government/utility to conduct a grid integration study for the specific project; and (ii) an incomplete } \\
\text { grid integration study that may not represent the reality of the grid. } \\
\text { If the project is based on this incomplete grid study, there is a potential risk of curtailment as the project would not } \\
\text { have been based on sound technical and commercial constraints. It is a risk that will arise during operation but is } \\
\text { linked to the development phase of the project, as it depends on where the project connects into the grid. }\end{array}$ \\
\hline
\end{tabular}

Source: World Bank. 2019. A Sure Path to Sustainable Solar. 
TABLE 4.2. Substation-based competitive bidding

\begin{tabular}{|c|c|}
\hline \multicolumn{2}{|c|}{ SUBSTATION-BASED COMPETITIVE BIDDING } \\
\hline \multicolumn{2}{|c|}{$\begin{array}{l}\text { The government identifies substations with available MW } \\
\text { capacity, and a certain MW capacity at each substation is } \\
\text { opened for bidding. }\end{array}$} \\
\hline+ & $\begin{array}{l}\text { It helps optimize the use of existing transmission } \\
\text { capacity in the deployment of solar projects, reducing } \\
\text { the potential cost to integrate them. It can proactively } \\
\text { drive grid investments needed for new VRE generation. }\end{array}$ \\
\hline $\mathrm{x}$ & $\begin{array}{l}\text { If the number of selected substations is too small, there } \\
\text { may be major competition for land around the substation } \\
\text { that would drive the PPA price up. }\end{array}$ \\
\hline \multicolumn{2}{|c|}{$\begin{array}{l}\text { Mexico developed such a scheme that has been very successful } \\
\text { in supporting a more controlled deployment of solar PV in the } \\
\text { country. Germany's premium and penalty scheme is a variation } \\
\text { of this scheme. }\end{array}$} \\
\hline
\end{tabular}

Source: World Bank. 2019. A Sure Path to Sustainable Solar.

\subsection{SUBSTATION BASED COMPETITIVE BIDDING}

\subsubsection{Description of the bidding model}

The Government of Vietnam through EVN/NPT would identify substations across provinces with available interconnection capacity limits for solar generation and open for bidding a certain MW capacity at each substation. The substation-linked model is recommended in the context of Vietnam as it helps optimize the use of existing transmission capacity in the deployment of solar projects and reduces both the potential cost to integrate VRE and the risk of curtailment.

\subsubsection{Key steps for substation-based bidding scheme}

The substation-based bidding key steps are:

a. EVN and NPT to identify potential substations. EVN and NPT identify a set of substations/feeders with available capacity (or substation/feeders at which minimal upgrades would be needed to integrate between 50 and $150 \mathrm{MW}$ of solar). They are expected to consider multiple relevant factors in deciding which substations could be integrating VRE, such as plans for other generation projects, transmission expansion, new demand centers, or system considerations (such as locating generation at the tail-end, etc.). A static and dynamic load flow analysis needs to be conducted to inform the selection.

b. EVN and MOIT with the support of the provinces to select the substations to be proposed for bidding. The final selection of the substations is done in a multi-criteria manner looking at:

- Technical grid availability at the given substation (as evaluated in step a.);

- Capacity limits for integration of VRE in that part of the grid;
- Land usage and availability (typically within $20 \mathrm{~km}$ ) around the substation-with a particular focus on environmental and social criteria;

- Cost of land in the nearby districts of the substation; and

- Solar irradiation around the substation.

c. MOIT/EVN to announce launch of competitive bidding with substation list. Once the bidding framework is finalized (bidding process, contractual risk allocation, template dossiers of invitation for qualification, template RFPs, etc.), MOIT/EVN launches the competitive bidding round by announcing the available substation and their associated MW capacity and setting out the eligibility/qualification criteria for bidders to qualify for the RFP stage. These eligibility/qualification criteria would be linked to the financial capacity of the IPP, its technical experience, and a given level of development for the site proposed by the IPP around the substation.

d. IPP to identify land around selected substation. The land is identified by the IPP around one of the identified substations. To be pre-selected as part of the competitive bidding scheme, the IPP needs to have identified pieces of land.

e. IPPs to submit their qualification package. The IPP presents (i) its financial strength and capacity to raise debt, (ii) experience in solar PV construction and operation, (iii) identified land details combined with a short pre-feasibility study of the project. The precise qualification documentation and eligibility/qualifications to meet are to be finalized by the Government of Vietnam's transaction advisor.

f. MOIT along with PPCs and EVN to select shortlisted IPPs and share the RFP package to the qualified IPPs. Based on the pre-qualification parameters, IPPs are shortlisted and the finalized RFP package is shared with them. The RFP package should include: (i) instructions to bidders and forms; (ii) a complete set of contractual agreements, consisting of the implementation agreement, PPA, connection agreement and investment license; (iii) all technical specifications for the construction and operation of the plant and the grid code. Additionally, the government can add the following documents to the RFP: (i) a list of permits needed by all IPPs before and during operation, (ii) a term sheet of guarantees and stable financing proposed by development finance institutions in coordination with the Government of Vietnam and (iii) a list of assumptions including tax treatment with a financial model that will be used to compare the financial proposals. 
g. IPPs to submit their technical and financial proposals. In the financial proposal, IPPs need to announce their lowest PPA purchase price. As part of their technical proposal, IPPs will outline (i) their proposed project location, current status of land use, explanation on satisfaction of conditions for land lease, allocation, conversion of land use purpose, estimated timeline to obtain land approvals, and (if available) the general land clearance and compensation plan, (ii) a technical feasibility study, (iii) technical qualifications, (iv) financial qualification, and (v) bank term sheets. A bid bond will be required with the IPP proposal submission.

h. IPP selection. The technical proposal is open and all the IPP meeting the technical requirements pass. The financial proposal is only open for the IPP that met the technical requirements. The IPPs with the lowest proposed PPA price win. If the government has more IPPs selected on the financial criteria for one substation than the available capacity at that given substation, the lowest priced project for that substation will win and the others will be discarded.

i. Bidding winner announced, contract signature and permits granted. Winning IPPs sign the PPA with EVN and are granted the investment license (directly if the competitive selection is hosted under the investment law and indirectly if not). Under a fast track program, PPC approves inclusion of the selected project into the local land use plan, issues decisions to lease/allocate land and allocate or convert land use purpose, and conducts land clearance/compensation procedures. IPPs will sign auxiliary technical agreements (including the Grid Connection Agreement) and obtain other permits and licenses (e.g., approval of environmental impact assessment (EIA), construction permit) for the project. As mentioned above, in the event where the Government of Vietnam decides to not host the competitive bidding under the investment law, the provinces could propose a fast track process for substation-based competitive bidding, with selected IPPs to be granted the investment license.

\subsubsection{Technical aspects}

EVN/NPT would set the capacity range or limits for a given voltage level. The typical capacity range and voltage level, considering multi-circuit lines/bays, are as follows.

\section{TABLE 4.3. Voltage and capacity range for solar capacity}

\begin{tabular}{|c|l|}
\hline VOLTAGE LEVEL & CAPACITY RANGE \\
\hline $110 \mathrm{kV}$ & $50 \mathrm{MW}-100 \mathrm{MW}$ \\
\hline $220 \mathrm{kV}$ & Up to $250 \mathrm{MW}$ \\
\hline
\end{tabular}

To ensure economies of scale and a better integration in the system, the substation-linked bidding leads to lower prices if the substations selected are transmission level voltages.

\subsubsection{Permits}

At RFQ stage. The IPP will have to obtain preliminary acceptance letter of provincial PPC for project site study and prepare the short pre-feasibility study for the project.

At RFP stage. The IPP prepares a technical feasibility study and has some land agreements.

Just after IPP selection. In relation to electricity sale and purchase: IPPs obtain EVN's in-principle acceptance to purchase power and sign the auxiliary technical agreements (including the Grid Connection Agreement) and the PPA with EVN. In relation to the project's land, PPC approves inclusion of the project's land into the relevant local land use plan. PPC issues decision on permitting the selected project to lease/ allocate with land or conversion of land use purpose. The IPP conducts land clearance and compensation procedures. The selected project will then be issued with the land use right certificate (LURC). In relation to construction and design, PPC/DOIT issues right of way approvals for the project's interconnection facilities. PPC or DOC issues construction permit(s) to the project. With respect to other licenses and approvals, PPC or DONRE issues EIA approval; local police department issues fire prevention and firefighting design approvals to the selected project.

After selection and prior to COD of the project. IPPs apply for the Electricity Operation License, with facilitation by MOIT/ EVN.

\subsection{SOLAR PARK COMPETITIVE BIDDING}

\subsubsection{Description of the bidding model}

The Government of Vietnam (in particular, PPC and EVN) will identify the site(s), conduct land clearance and invest in key infrastructure if agreed upon (fencing, water access etc.). EVN/NPT and/or the provinces undertake investments for the solar park infrastructure. Once the project reaches "ready for competitive bidding status," with all required consent and approvals obtained, a competitive bidding procedure begins and the winning IPPs will be responsible for arranging the financing, construction, and operation of the solar project. 


\section{TABLE 4.4. Solar park competitive bidding}

\section{SOLAR PARK COMPETITIVE BIDDING}

The government identifies the site(s), conducts land clearance, and constructs infrastructure for the solar park that can range from the evacuation line to basic elements (such as the fence, roads, street lighting, etc.). Once the project is ready for competitive bidding, the bidding procedure begins and the winning IPP is responsible for the financing, construction, and operation of the solar project.

$+\quad$ The solar park significantly lowers development risks (particularly those associated with acquiring land and consents) and shortens the development timeline for the private sector, which results in cost savings and lower PPA tariffs.

The implementing agency will need time and an upfront budget to develop the solar park facility before conducting a tender There is a risk that the infrastructure expected from the government is not built in the agreed timeline with the winning IPP, leading to an extra cost for the government. It is important to integrate such potential delays in the assessment of what the government will build and what it will leave to the IPP (e.g., the interconnection line).

India and Morocco championed the public solar park scheme, leading to competitive PPA prices. The World Bank Group developed the scaling solar concept that has reduced upfront development risks. It was successful in Zambia and Senegal.

Source: World Bank. 2019. A Sure Path to Sustainable Solar.

\section{TABLE 4.5. Solar park infrastructure optimum allocation between private and public parties}

\begin{tabular}{|c|c|}
\hline ELEMENTS & OPTIMUM PARTY IN CHARGE \\
\hline $\begin{array}{l}\text { Solar park land, including identification } \\
\text { of rights of way and ownership }\end{array}$ & Public party procuring the solar project-usually the state utility. \\
\hline Fencing & $\begin{array}{l}\text { Best if done by the public party to ensure that new settlements are not built after purchase } \\
\text { and during procurement. }\end{array}$ \\
\hline Land technical preparation & $\begin{array}{l}\text { If the site is complex and if there is more than one IPP in the same park, it is best if the public } \\
\text { party prepares the land, especially with regard to the earthworks. }\end{array}$ \\
\hline $\begin{array}{l}\text { Connection line from plant to } \\
\text { substation }\end{array}$ & $\begin{array}{l}\text { If there is more than one IPP in the same park, this would be best done by the public party. } \\
\text { Otherwise, a secured right of way would be enough. }\end{array}$ \\
\hline Water supply and drains & $\begin{array}{l}\text { To be done by the public party if water supply and flooding pose risks and if several IPPs } \\
\text { share the park. }\end{array}$ \\
\hline Weather station & May be handled by the public party to optimize costs. \\
\hline Fire station & May be handled by the public party to optimize costs. \\
\hline Main road & May be handled by the public party to optimize costs. \\
\hline Street lighting & May be handled by the public party to optimize costs. \\
\hline Internal access roads & May be handled by the public party to optimize costs. \\
\hline
\end{tabular}

Source: Adapted from Bridge to India (2017).

This scheme can attract larger and more risk adverse companies. Global investors, who are generally wary of the local regulatory and development risks, are more likely to participate with this scheme. The solar park significantly lowers development risks, in particular with land acquisition and consents; it also shortens development timeline for the private sector, which results in costs savings and lower PPA tariffs.

The main constraint in implementing this scheme is limited institutional capacity of governments to manage the process and lack of budget provisions for undertaking such infrastructure work. If budget constraints arise, the investment in the park infrastructure can be limited to land clearing and fencing. ${ }^{1}$

Contractual arrangement between the Government of Vietnam (as the solar park agency) and the IPP (typically in the form of a Solar Park Agreement) would be required to estab- lish contractual rights and duties between both parties for the term of the PPA.

The Government of Vietnam can recover the cost of development, investment, and maintenance of common infrastructure and land through (i) a yearly solar park fee paid by the IPP for the term of the PPA or (ii) receiving a monetary sum by means of leasing the right to use the solar park infrastructure through a lease agreement. EVN recovers the investment in transmission infrastructure through appropriate regulated transmission charges. The solar park fees and transmission charges have to be determined and fixed prior to the bidding process and will be clearly stated as part of the bid documents.

The solar park fee can be used to promote local development in the province where the solar park is located. 


\subsubsection{Key steps for solar parks}

The key steps for the solar park scheme are described below.

a. EVN and NPT to identify potential substations. EVN and NPT identify a set of substations with available capacity of a quantity suitable for bidding based on similar criteria than for the substation-based bidding

b. PPC with the support of MOIT and EVN to identify land around selected substation. The PPC, with the support of EVN and MOIT, identifies land suitable for development of the solar project (typically a minimum contiguous size of c. 200 ha which is needed for $150 \mathrm{MW}$ ) and its right of way to the substation.

c. Solar park preparation prior to launching the bid. Once the land, along with its right of way, is selected, EVN with the support of PPC obtains necessary approvals to develop the solar park infrastructures (fencing, water access (if any), road and connection line to the substation). PPC approves inclusion of the selected project into the local land use plan and issues decision to lease/allocate with land or conversion of land use purpose. A feasibility study, an environmental and social impact assessment (ESIA), and a geotechnical study are conducted. Based on the results of the resettlement plan, EVN conducts land clearance/ compensation procedures and builds a fence. EVN with PPC obtains the EIA approval, and the construction permit for the project.

d. MOIT/EVN to announce launch of competitive bidding with solar park. Once the bidding framework is finalized (bidding process, contractual risk allocation, template dossiers of invitation for qualification, template RFP etc.), MOIT with PPC launches the solar park competitive bidding by announcing the location of the solar park and its key parameters, and by issuing the dossiers of invitation for qualification, setting out the criteria to be met to be eligible for RFP stage. These qualification criteria would be linked to the financial capacity of the IPP and its technical experience.

e. IPPs to submit their qualification package. The IPP presents (i) its financial strength and capacity to raise debt, and (ii) experience in solar PV construction and operation. The precise qualification documentation and eligibility/qualifications to meet will be finalized by the government's transaction advisor. f. MOIT with PPC and EVN to select shortlisted IPPS and issue the RFP package. Based on the pre-qualification parameters, IPPs are shortlisted and the finalized RFP package is shared with them. The RFP package encompasses the solar park feasibility study with a grid integration analysis, the ESIA and its environmental and social plan, a geotechnical analysis, land ownership details, and the solar park implementation agreement and the permits granted. This is in addition to what was mentioned in the substation-based RFP package.

g. IPPs to submit their technical and financial proposals. In the financial proposal, IPPs need to announce their lowest PPA purchase price. As part of their technical proposal, IPPs will provide their (i) technical qualifications, (ii) financial qualification, (iii) bank term sheets. A bid bond will be required with the IPP proposal submission.

h. IPP selection. The technical proposal is open and all the IPP meeting the technical requirements pass. The financial proposal is only open for the IPP that met the technical requirements. The IPPs with the lowest PPA proposed price win.

i. Bidding winner announced, and contract signature. Winning IPPs sign the PPA and the solar park agreement with EVN and are granted the investment license.

j. EVN to build the transmission line to the substation. After the IPP is officially selected, EVN can start the transmission line construction and has around 12 months to finish its construction.

\subsubsection{Permits}

Prior to the bidding process, MOIT issues approval for inclusion of the Solar Park (together with its substation/ interconnection plan) into the PDP if the flexibility on unallocated plant has not yet been approved. EVN obtains the land allocation, the construction permit, and the EIA permit

Just after IPPs selection, IPPs obtain the Investment Registration Certificate, enter into an agreement with EVN for solar park infrastructure payment, sign the PPA, receive final approval from PPC or DOC through the construction permit specific to the solar power plant, and obtain the local police department fire prevention and firefighting design approvals to the selected project.

After selection and prior to COD, IPPs apply for the electricity operation license, with facilitation by MOIT/ EVN. 


\section{ROLES AND RESPONSIBILITIES}

\subsection{SUBSTATION-BASED ROLES AND RESPONSIBILITIES}

The roles of the principal entities in substation-based competitive bidding are defined in table 5.1.

\section{TABLE 5.1. Roles and responsibilities under substation-based competitive bidding}

\begin{tabular}{|c|c|c|}
\hline ROLE & RESPONSIBILITY & STAKEHOLDER(S) \\
\hline $\begin{array}{l}\text { Bidding selection } \\
\text { committee }\end{array}$ & $\begin{array}{l}\text { The committee (i) develops with the transaction } \\
\text { advisors the bidding documentation and framework; and (ii) } \\
\text { launches, implements, and concludes the } \\
\text { IPP selection process. }\end{array}$ & $\begin{array}{l}\text { MOIT and/or EVN leads the process with the } \\
\text { support of EVN/MOIT and the PPC for the area in } \\
\text { which each substation/solar park is located. PPCs } \\
\text { must be fully involved, as the selection process } \\
\text { leads to the approval of the investment license. }\end{array}$ \\
\hline PPA signatory & $\begin{array}{l}\text { The PPA signatory signs the PPA with the IPP and } \\
\text { pays for the electricity provided by the IPP at the price } \\
\text { determined through competitive bidding. }\end{array}$ & $\begin{array}{l}\text { EVN, but this could change after the electricity } \\
\text { market is fully in place; see Annex } 1 .\end{array}$ \\
\hline $\begin{array}{l}\text { Selection of } \\
\text { substations/ } \\
\text { feeders and their } \\
\text { capacity }\end{array}$ & $\begin{array}{l}\text { Substations and feeders are selected as part of a larger } \\
\text { technical study of the grid so as to ensure minimal } \\
\text { VRE integration constraints are met and that suitable land is } \\
\text { available around the substation. }\end{array}$ & $\begin{array}{l}\text { EVN/NPT/Power Corporations (PCs), with the } \\
\text { support of PPC and MOIT }\end{array}$ \\
\hline $\begin{array}{l}\text { Power plant } \\
\text { owner }\end{array}$ & $\begin{array}{l}\text { The plant owner is responsible for (i) financing, building, } \\
\text { and operating the solar power plant; and in the case of } \\
\text { substation-based competitive bidding: (ii) identifying land; } \\
\text { and (iii) paying resettlement compensation. }\end{array}$ & IPP \\
\hline
\end{tabular}

\subsection{SOLAR PARK COMPETITIVE BIDDING ROLES AND RESPONSIBILITIES}

The roles and responsibilities in solar park competitive bidding (table 5.2) are similar to those for substation-based competitive bidding with one key difference relating to the role of the IPP in land selection.

\section{TABLE 5.2. Roles and responsibilities under solar park competitive bidding}

\begin{tabular}{|l|l|l|}
\hline ROLE & RESPONSIBILITY & STAKEHOLDER(S) \\
\hline $\begin{array}{l}\text { Solar park land } \\
\text { selection }\end{array}$ & $\begin{array}{l}\text { The land selection must be aligned with the land } \\
\text { master plan and with the goal of minimizing } \\
\text { environmental and social impacts. }\end{array}$ & PPC with the support of MOIT and EVN \\
\hline $\begin{array}{l}\text { Land clearing for } \\
\text { solar park }\end{array}$ & $\begin{array}{l}\text { People on the selected land are compensated, and } \\
\text { full ownership is transferred to the stakeholder. }\end{array}$ & PPC or EVN \\
\hline Solar park agency & $\begin{array}{l}\text { Technical development, financing, and construction of the } \\
\text { infrastructure (fence and transmission line) and operation } \\
\text { and maintenance (O\&M). }\end{array}$ & public entity (PPC or EVN) \\
\hline
\end{tabular}




\section{BIDDING FRAMEWORK}

The bidding framework provides the framework for procurement of the entire solar program. It encompasses (i) procurement issues, and (ii) contractual issues. Specifically, it includes details of the bidding mechanisms, procurement framework, and contractual arrangements that are to form the basis for the contracts. Each of these parameters enables a sustainable and scalable bidding program by balancing risk among stakeholders during the bidding process and over the life of asset.

The parameters are integrated into national regulations, usually under a ministerial decree. A high-level plan for the allocation of procurement and contractual risks needs to be developed by the government in partnership with the private sector. The bidding framework should be further detailed and refined for a specific phase of the program when the related procurement begins.

\subsection{BIDDING MECHANISM}

Based on market inputs and the level of competition, the bidding agency determines the bidding mechanism, which includes the procedures to be followed in bidding, qualification criteria for the selection of IPPs, and the criteria for winner selection, including provisions for iterative price discovery.

\section{Recommendations on each of these aspects follow.}

a. Bidding process. An RFQ/RFP two-envelope process for running the pilot solar competitive bid is recommended for use in Vietnam. In this type of bidding process, the auctioneer issues an RFQ for qualification of IPPs. Qualified IPPs then receive the RFP. IPPs submit a technical proposal (envelope one) evidencing the required qualifications/eligibility and a financial/tariff proposal (envelope two) for the eligible project.

b. Qualification criteria. To ensure participation of proven IPPs in the bidding process, the bidding process must test IPPs for both technical capabilities and financial capabilities:

- Technical capabilities shall include the experience of IPPs in the development and construction of projects of similar capacity. The bidding agency may choose to consider experience gained on infrastructure projects other than solar projects.

- Financial capabilities shall test the ability of IPPs to secure long-term financing (loans and equity). Experience in financial closure of similar projects in similar geographies may be considered. Financial indicators such as net worth may be used to establish the equity capabilities of an IPP.

c. Iterative price discovery mechanism. An iterative bidding process typically occurs in real time via the internet. It can achieve greater price reductions than those to be had through a static, paper-based process. However, such a system requires market maturity, preparation, and competition if it is to yield positive results. Hence, for the initial pilot bidding a sealed envelope financial bid is recommended. The iterative price discovery process may be introduced later, after gauging bidders' interest and the maturity of the market.

d. Winner selection. Because Government of Vietnam's current focus for the solar industry is to attract the most cost-effective international technology and funding, it is recommended that winners be selected based on the lowest tariff submitted. 


\subsection{PROCUREMENT FRAMEWORK}

The high-level procurement framework reflects decisions on the following criteria: (i) the payment mechanism, (ii) tariff indexation; and (iii) the ceiling tariff.

Recommendations on each criterion follow

a. Payment mechanism. Energy-based payments, i.e., net metered energy exported by the solar project in MWh/ $\mathrm{kWh}$, are recommended for the tariff quoted by IPP in a solar bid instead of a MW-based payment mechanism.

b. Tariff indexation. The tariff structure should be indexed to inflation and, in the short-term, fully indexed to foreign currency. The medium-term vision should be for partial indexation to U.S. dollars or full VND payments (depending on conditions in the domestic lending market).

c. Ceiling tariff. Some countries share this information to ensure that the PPA price of the project is affordable for the country, but it may be interpreted as a price signal to the market, inducing bidders to offer tariff proposals in the ceiling range that are not as competitive as they might have been. On the other hand, if the ceiling tariff is too low, the tender may be undersubscribed. For the pilot competitive bidding, the FIT can be used as the ceiling tariff to ensure that the competitive bid will be lower than the FIT.

\subsection{CONTRACTUAL FRAMEWORK}

The contractual framework comprises provisions on several subjects to be included in the PPAs entered into with qualified IPPs: (i) the PPA term; (ii) off-take arrangements and curtailment; (iii) response to legislative changes; and (iv) termination and arbitration.
The contractual framework defines the risk-sharing mechanism between the parties to the contract. The discussion here is focused on provisions to improve the bankability of the PPA by attracting lower-cost financing, encouraging international investment, and stimulating greater competition.

Recommendations on each of these subjects follow.

a. PPA term. In view of the lifetime of solar power plants and because solar projects are CAPEX intensive, a PPA term of 25 years is recommended for projects contracted under the bidding scheme.

b. Off-take arrangement. The PPA should include a provision for deemed generation beyond a specified number of hours. In a competitive bidding scenario, reduction of such curtailment risks in solar projects enables a tariff reduction, since developers would otherwise have priced them into their bids.

c. Change in law. Considering changing regulatory dynamics in Vietnam (such as the introduction of VWEM), it is recommended that the IPP is protected from any change in law by a letter of support from the Government of Vietnam. Investors should be compensated for the impact of legislative changes either through a compensatory tariff mechanism or through other related mechanism deemed appropriate by the regulatory authority.

d. Termination and arbitration. It is recommended that provisions for termination due to seller's or buyer's default should be included in the PPA, along with a corresponding compensation mechanism and a provision for international arbitration. 


\section{SOCIO-ECONOMIC BENEFITS STRATEGY}

Based on a supply chain analysis conducted in $2018^{2}$ and described in Annex 3, the 12 GW PV target from the revised PDP 7 is expected to support as many as 25,000 full-time jobs in project development, services, and O\&M annually through 2030. Solar PV-related employment in Vietnam will derive from (i) development and operation of solar PV power plants, and (ii) manufacturing of equipment. The first category comprises jobs in development, design, construction, and commissioning of solar PV plants. Jobs created in connection with project implementation tend to be temporary and to disappear once the plant is commissioned and generating power. The implementation phase is followed by O\&M, which extends for the duration of the plant's life cycle.

Job creation in manufacturing is expected to reach nearly 20,000 full-time equivalents by 2030. Most of these jobs will be export-driven and depend on Vietnam maintaining its current share of the global solar PV market. That, in turn, will depend on the country retaining its attractiveness to international solar PV manufacturers.

\section{FIGURE 7.1. Job creation in project development, services, and O\&M expected from Vietnam's 12 GW solar PV target, 2017-30 (thousands of full-time equivalent positions)}

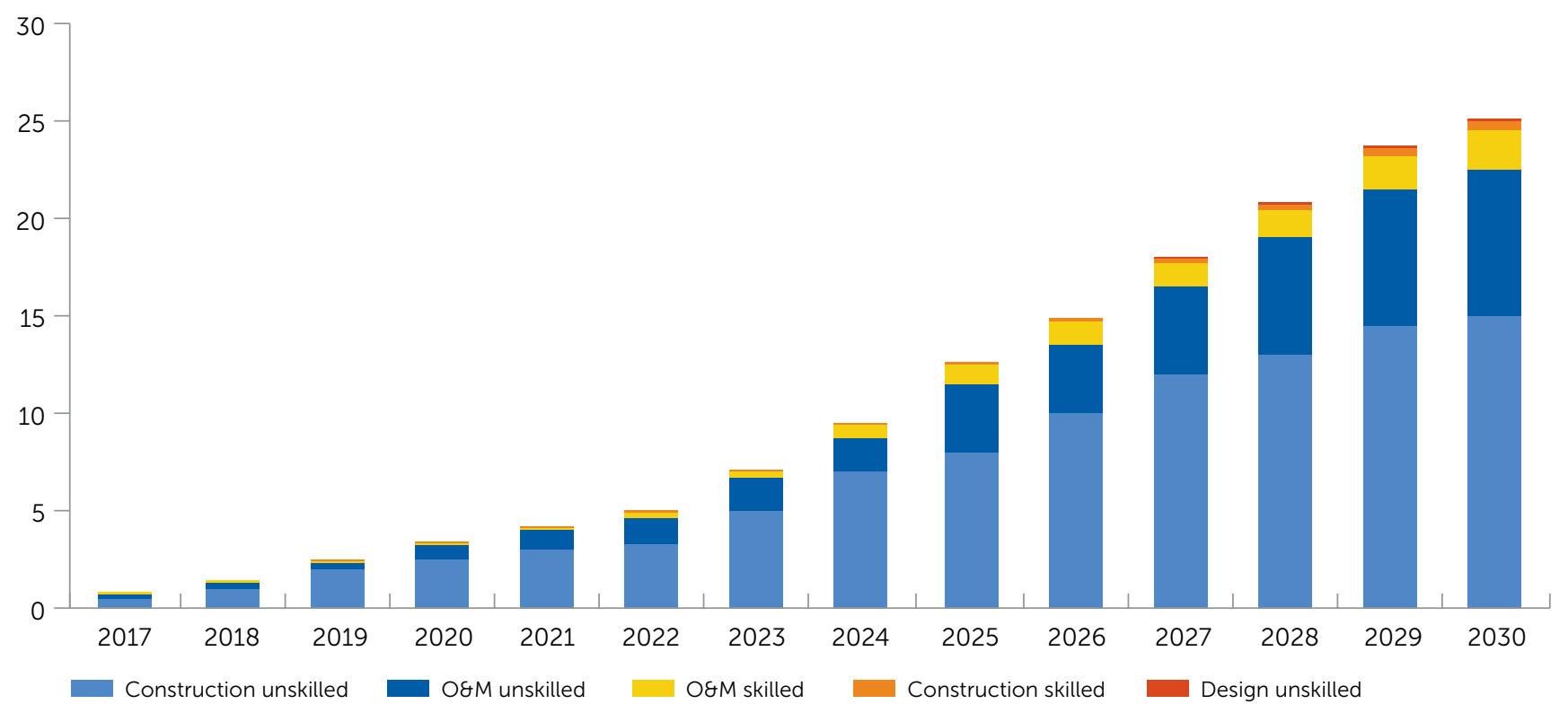

Source: World Bank. 2018. Assessment of Vietnam's Solar PV Supply Chain

2. World Bank. 2018. Assessment of Vietnam's Solar PV Supply Chain. http://pubdocs.worldbank.org/en/301671539903264866/Vietnam-Solar-PV-SupplyChain-Assessment-10May2018 


\section{FIGURE 7.2. Manufacturing jobs expected to be created by achievement of Vietnam's 12 GW solar PV target, 2017-30 (thousands of full-time equivalent positions)}

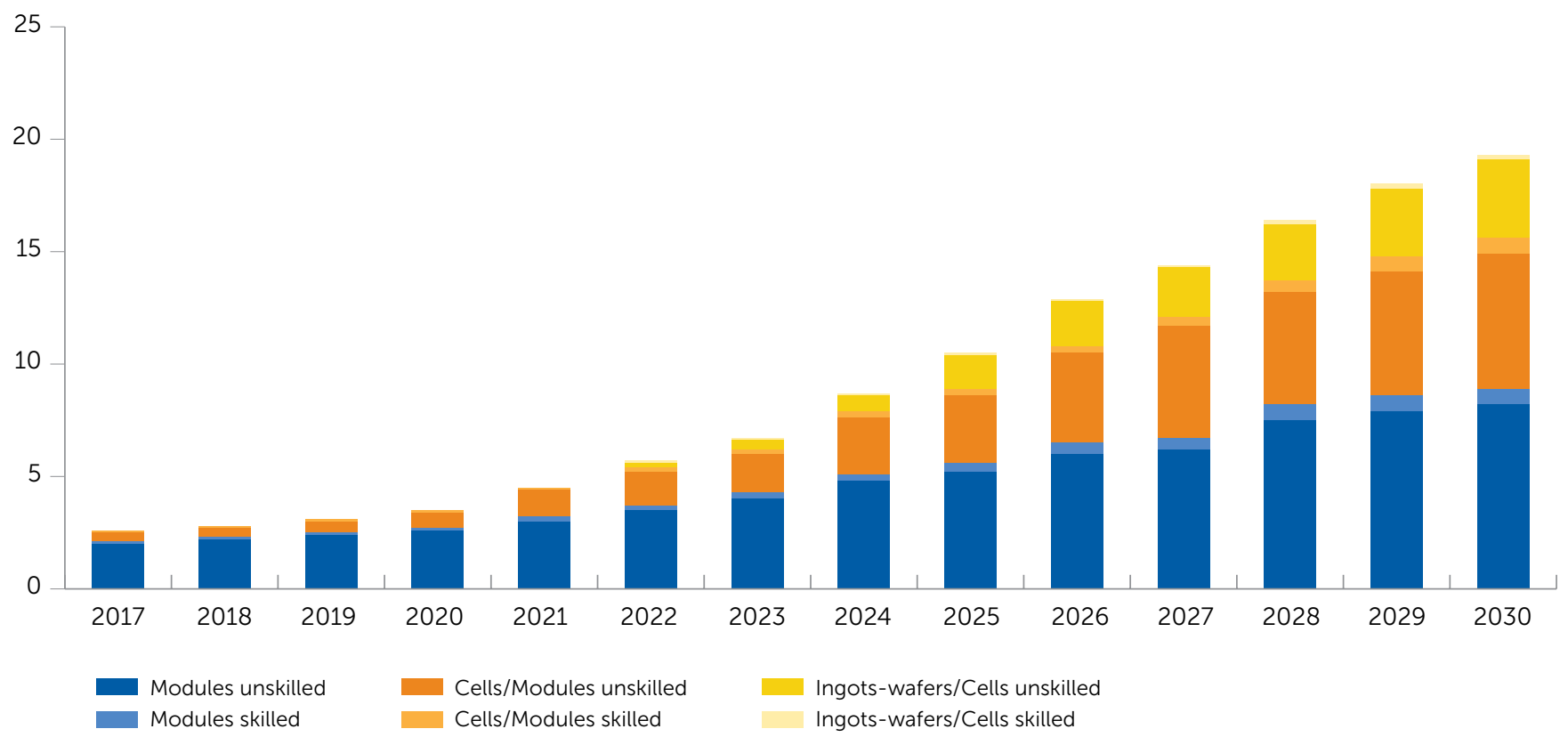

Source: World Bank. 2018. Assessment of Vietnam's Solar PV Supply Chain

Sound planning with medium-term targets will allow countries to maximize the socio-economic benefits from solar projects implemented in accordance with a sustainable and integrated roadmap. Benefits can be maximized in various ways, as described below.

a. Provide visibility locally and internationally. To support the development of local industry, the Government of Vietnam may wish to consider (i) informing the market of the programs' features, including local and industrial development targets, and (ii) taking local suppliers through the solar value chain to help them identify relevant opportunities and position themselves as needed. The creation of a business cluster could also help local players benefit from the solar program as it is deployed, disseminate adequate knowledge on the solar value chain, provide relevant training in coordination with professional training institutions, help local companies gain visibility, and link them to any international players involved in the bidding processes.

b. Facilitate the assessment of local opportunities. The Government of Vietnam may wish to conduct external studies in accordance with best practices to assess the potential of the local market in the solar value chain and to share the results with prequalified bidders to facilitate bidders' exploration of local opportunities as partners or subcontractors. Meetings could be organized between local players and prequalified bidders (and their main subcon- tractors for engineering, procurement, construction, operation, and maintenance).

c. Enhance the position of local players and local jobs in the value chain. The government might map local players and their skills, then identify how they might fill gaps in the solar value chain. Any theoretical assessment could be improved by benchmarking local players against preselected subcontractors by asking, for example, prequalified bidders to explain whether they intend to preselect local subcontractors and, if not, why not. This information would help public stakeholders design a tailor-made program to enhance the position of local players along the value chain. According to an IRENA study on jobs in renewables, operation and maintenance jobs require specific attention, as they constitute more than half of the jobs associated with a solar PV plant.

When developing solar parks, the Government of Vietnam should consider measures to ensure that people living around the parks become direct beneficiaries of the new infrastructure. One way to do this would be a yearly park fee that could be applied to fund development projects or the hiring of local staff. Carrying out a socio-economic study to assess the needs of local communities would help in the design of tailor-made programs to meet local needs in coordination with the public stakeholders involved. One useful focus of these programs could be gender. 
While the Government of Vietnam understands community needs and how to meet them, it often lacks the means to finance the necessary measures. The bidding process could include provisions requiring the IPP to allocate a small percentage of the capital expenditure (e.g., 1 percent) for use by governments on local development. For example, in South Africa, projects mandated under the Renewable Energy Independent Power Producer Procurement Programme are required to set aside a percentage of total project revenues for socio-economic development to benefit local communities. This is the case with the Redstone 100 MW CSP project, which commits to a 2.5 percent community trust. Set up as a not-for-profit organization, the trust will benefit local communities living around the project site, particularly women, who are involved as trustees. Distributions received by the trust must be applied to specific community development programs, including health care, education, training, and development. 


\section{CONCLUSION}

To replace the FIT, the Government of Vietnam is preparing the country's first solar competitive bidding program with the intention of scaling up the deployment of solar power at competitive electricity tariffs. With the support of the World Bank, the government is designing the program based on the present strategy developed through consultations with various ministries and the private sector.

Key aspects of the strategy requiring government's decision are: (i) the roles and responsibilities of the various public and private parties, (ii) whether changes need to be made to existing law, (iii) the types of deployment schemes that are best suited to Vietnam's circumstances, and (iv) what risks the Government of Vietnam will internalize and what mitigation instruments it might offer to IPPs. Clarification of these points before IPPs are selected will speed the selection process, reduce the chances of procurement failure, and provide a long-term vision for deploying solar projects. From the IPPs' perspective, a clear government strategy lessens the concerns of potential investors about the legal framework, the selection process, and other development matters.

The following points deal with these aspects of the strategy.

- Solar deployment targets and timeline. To signal to private investors that Vietnam represents a long-term potential investment in the solar market, the country must establish medium-term solar deployment targets with clear timelines. International experience suggests that bids should be launched in a regular manner, such as every 12 or 18 months, as specified in the official national generation plan. Vietnam could pilot competitive bidding in 2020/2021 through three different schemes totaling 1.2 GW: (i) substation-based competitive bidding for a capacity of 500 MW, (ii) a 200 MW floating solar park, and (iii) ground-mounted solar parks with a combined capacity of $500 \mathrm{MW}$. After the pilot phase, it is recommended to launch bids for 1-2 GW of capacity each year, comprising a mix of substation-based bids and solar parks, as described in Section 2 and 4.

- Legal framework. Current regulations in Vietnam do not specifically provide a framework for competitive selection of IPPs. Therefore, the Government of Vietnam should provide additional guidance related to the existing law and decide under which law the competitive selection in the energy market will be hosted. Based on extensive discussions with MPI, MOIT, and other ministries, and on a full legal review, the investment law is recommended. A Prime Minister's Decision will be needed to provide guidance on two fronts: first, cooperation among MOIT, EVN, and the local authorities (PPCs and DPIs) related to the bidding process, particularly the criteria and procedures to be used in the evaluation and selection processes, and the roles and responsibilities of each entity; and, second, on deployment schemes and the high-level bidding framework (i.e., payment mechanism, tariff structure, the term of PPAs, and potential government support).

To ensure that the inclusion of projects into the PDP is not becoming a bottleneck, the Government of Vietnam needs to create some flexibility over project allocation in the PDP. It would be optimal for the PDP to permit unallocated solar capacity-that is, to nominate a quantity of capacity in the PDP and reserve it for the winning IPP/ project under the competitive selection.

- Deployment schemes. After a thorough review of various competitive schemes used internationally and the key challenges Vietnam is facing, two deployment schemes are recommended. These are (i) substationlinked competitive bidding, and (ii) solar park com- 
petitive bidding (ground-mounted and floating). These schemes seek to address the key constraints faced in Vietnam, namely grid availability, risk of curtailment, and complex land allocation. Both schemes aim to reduce the development risks perceived by IPPs, thus lowering the risk premium in the cost of capital. The main outcome expected is a lower tariff.

- Roles and responsibilities. The key public actors involved in the competitive bidding IPP selection are MOIT, MPI, EVN, and PPC.

- Bidding framework. The core recommendations for the high-level bidding framework are:

a. Bidder qualification. After technical qualification, winners are selected based solely on price, with the project being awarded to the bidder offering the lowest price.

b. Payment structure. The payment structure is in MWh or kWh, not in MW;

c. Tariff structure. The tariff structure is to be indexed to inflation and, in the short-term, to be fully indexed to foreign currency. The medium-term goal should be partial indexation to U.S. dollars or full payments in VND, depending on the state of the domestic lending market at the time of the tender.

d. PPA term. The PPA term should be 25 years.

e. Change in law. A letter of support from the Government in the event of a change in law should be included in the PPA.

f. Arbitration. A provision specifying international arbitration of disputes is recommended.

- Socio-Economic benefits strategy. Key steps to maximize the socio-economic benefits of solar development are as follows:

a. Provide visibility, locally and internationally.

b. Facilitate the assessment of local opportunities.

c. Maximize benefits for local communities.

d. Manage expectations to ensure better results.

e. Enhance the position of local actors and local employment in the value chain. 


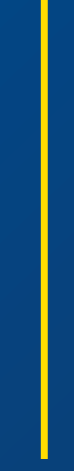

ANNEXES 



\section{ANNEX 1 \\ THE VIETNAM POWER SECTOR REFORM PROGRAM}

Decision 63 issued in November 2013 sets out a roadmap for restructuring the power market and establishing a competitive market-driven environment. The objectives of the reform include (i) developing a competitive electricity market in a phased and sustainable manner; (ii) attracting new investors to the power sector; (iii) reducing the state's investment in and subsidies of the power sector; (iv) improving the efficiency of the power sector and ensuring a stable and reliable supply of electricity; and (v) reducing the pressure to increase electricity tariffs.

Different stages of market development envisaged as part of the reforms are:

a. Level 1: Competitive power generation market (Vietnam competitive generation market, VCGM). The key characteristic of VCGM is that power generators can enter and sell electricity to EVN, the single buyer, at competitive prices.

b. Level 2: Competitive wholesale power market (Vietnam wholesale electricity market, VWEM). The key characteristic of VWEM is that all power generators and wholesale power distributors will enter the market. Therefore, in addition to EVN, there will be other wholesale buyers.

c. Level 3: Competitive retail power market. At this level, distribution company activities are split into network management, network operations, and retailing. End users are free to choose their suppliers.

Presently, the VCGM hosts two kinds of participants. Direct trading generators (DTGs) are centrally dispatched and have SPPAs in place. Indirect trading generators (ITGs) are not dispatched centrally but instead are scheduled ahead of time. ITGs include: BOT projects, Strategic Multi-purpose Hydro Plants (SMHPs), and various other exceptions.

\section{OPTIONS TO IMPROVE LONG-TERM GENERATION IN VIETNAM}

Intelligent Energy Systems (IES), in collaboration with SW Advisory (SWA) and Energy Market Consulting Associates (EMCa), has presented a report on options to improve longterm generation adequacy in Vietnam as part of their work for the Asian Development Bank under their Vietnam Power Sector Reform Program. The focus of the report is longerterm arrangements.

In summary, until the VWEM market matures, the report recommends the following structure as an interim measure, where EPTC (EVN) operates as the IPP trader on behalf of the developer unless the developer elects to operate directly in the VWEM as the trader.

According to the report, once the marker mature, the best long-term option for VWEM participation is to require all new generation (including solar) to participate in the VWEM. In the longer term, once the market matures, the following structure is recommended.

Moreover, the report recommends migrating from the present physical PPA regime to contracting based on financial PPAs, with payments based on a contract for differences. This would apply to all new projects across all technologies, including solar. Effectively requiring the project developers to recover the cash flows from the spot market and EVN (in the interim) or the PCs (in the long term) for the differences as quoted in the tender prices. 
FIGURE A1.1. Interim VWEM

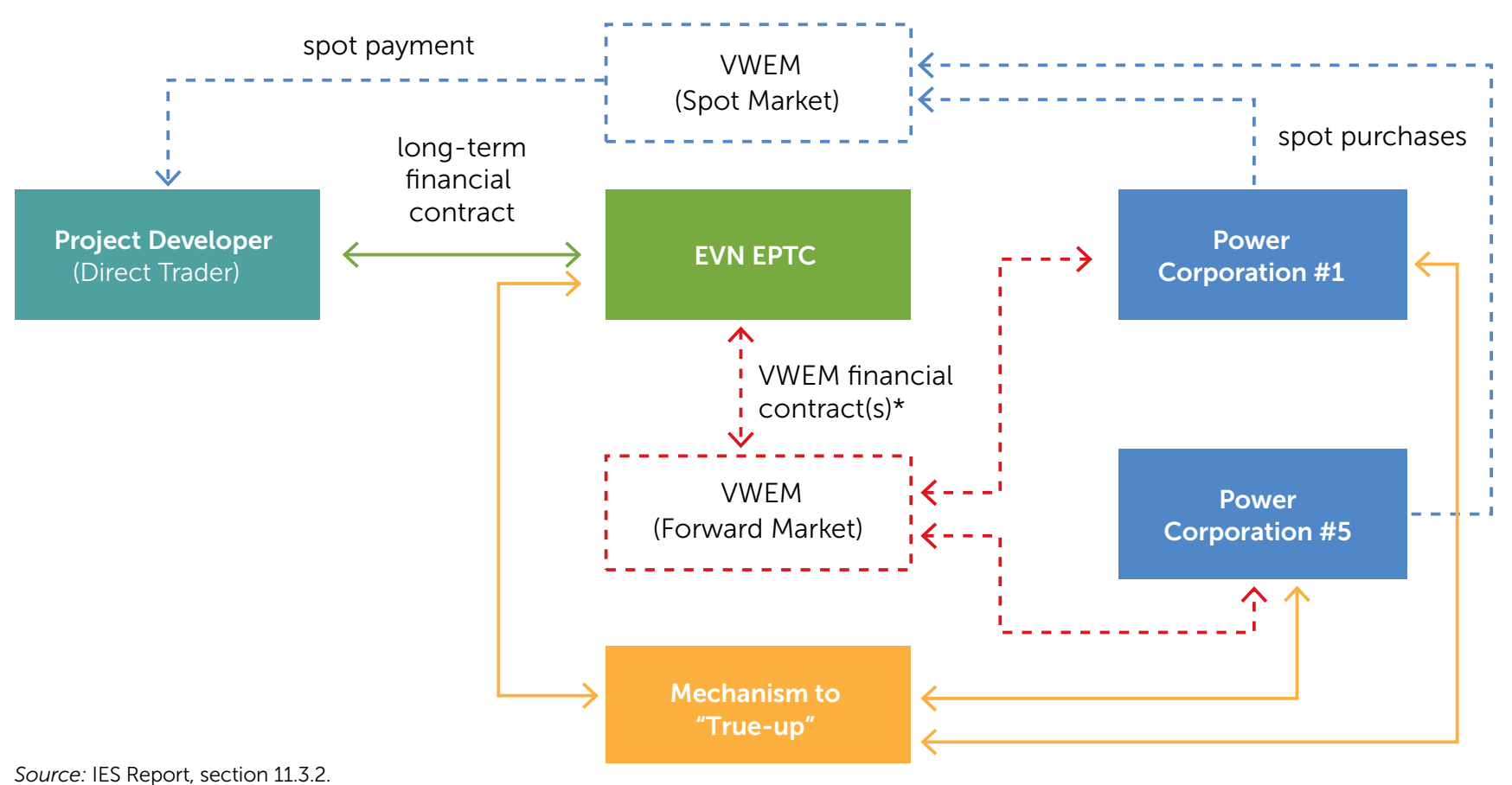

Source: IES Report, section 11.3.2.

FIGURE A1.2. Mature VWEM Structure

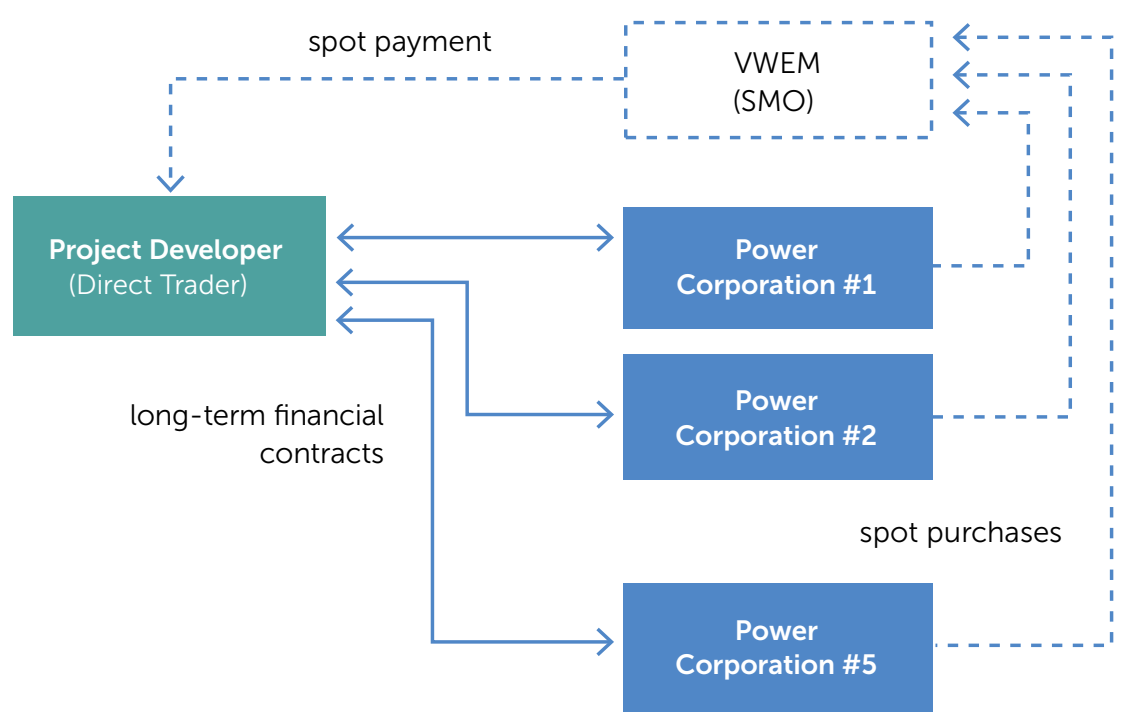

Source: IES Report, section 11.3.2. 


\section{LONG-TERM RECOMMENDATIONS FOR THE SOLAR COMPETITIVE BIDDING PROGRAM}

Migrating from the present physical PPA to financial PPAs accompanied by a contract for differences, even as an interim measure, requires that the following issues be explored:

a. Depth of the wholesale electricity market. The quantity of energy procured through the market to meet demand, and the number of transactions involved, indicate the market's maturity. Greater market depth implies visibility of market prices and reduces volatility resulting from sudden variations in supply or demand.

b. Counterparty credit risk. The System and Market Operator (SMO)'s creditworthiness plays a critical role in the success of solar competitive bidding. The SMO's credit rating will be influenced by the creditworthiness of retail PCs trading entities such as EVN, and other market participants. Thus, until the market matures, solar projects and bidding mechanisms linked to the VWEM spot market would require developers to rely on spot market prices backed by the SMO

c. Attracting international finance. Financiers and investors may not accept PPAs that are based on a contract for differences instead of a physical PPA. For the financial market, including international financiers, to have confidence in the rules of the VWEM, that market will need to show maturity and market depth, as discussed earlier.

Therefore, tenders held during the transition from physical PPAs to contracts for differences could reveal higher tariffs as bidders factor in revenue uncertainty related to the performance of the VWEM.

Thus, in line with Decision 63, it is recommended that solar projects should continue to be based on physical PPAs until the VWEM market fully matures.

\section{LEGAL CONSIDERATIONS}

Looking ahead to the next phase of VWEM, MOIT issued Circular No. 45/2018/TT-BCT dated 15 November 2018 with an effective date of 1 January 2019 (Circular No. 45), to provide guidelines on the operation of the VWEM. Circular No. 45's guidelines on the operation of VWEM have general implications for renewable power projects other than hydropower. Under the guidelines, non-hydropower renewable power projects with installed capacity of more than $30 \mathrm{MW}$ may "elect to participate" in the VWEM. Those that do will be subject to the legal and regulatory provisions applicable to power generators participating in the VWEM. Other non-hydropower renewable power projects (i.e., those with installed capacity of $30 \mathrm{MW}$ or less) can elect to participate in the VWEM indirectly - that is, without directly offering a tariff and without applying the VWEM tariff mechanism. ${ }^{3}$

As a next step to supplement the legal framework for implementation, the Electricity Regulatory Authority of Vietnam (ERAV) will have to formulate guidelines on participation that apply specifically to non-hydropower renewable power projects.

\section{RECOMMENDATIONS FROM THE LEGAL PERSPECTIVE}

Under the current PPA model for solar power projects, power sellers have the right to elect to participate in the wholesale power market as described in applicable regulations on competitive power markets. If a power seller elects to participate in the VWEM, it must provide 120 days' advance written notice to the power purchaser and to the ERAV. In such cases, the parties to the PPA may unilaterally terminate the existing PPA. This mechanism is provided as an alternative for solar power sellers to consider. ${ }^{4}$ Government of Vietnam should consider whether to continue to include this type of physical PPA in the solar competitive bidding framework.

If the Government of Vietnam wishes to encourage solar power developers to participate in the VWEM once it matures, it should weigh the question of providing incentives for solar and other non-hydro renewable power projects. In addition to addressing counterparty credit risk related to the SMO, among other things, the government may wish to consider including clear protections against changes in law in the contractual framework. Developers of projects with a fixed tariff secured under a solar competitive bidding program (as under the FIT program) will want to know that the Government and other power purchasers (off-takers) will bear the risk of legal changes after the date of the executed PPA. The necessary reassurance can be provided by including in the model PPA or legal framework a specific provision on changes in law and adjustments to electricity payments during the migration from physical PPAs under the solar competitive bidding program to financial PPAs under the VWEM.

3. Articles 4.2 and $4.3(\mathrm{~b})$ and 3.21 of Circular No. 45. 4. Circular No. 16/2017/TT-BCT of the MOIT, Annex II, Article 9.3. 


\section{ANNEX 2 \\ RESULTS OF GEOSPATIAL ANALYSIS}

This annex presents the results of a countrywide geospatial analysis conducted to determine where solar generation could and should be developed as a function of levels of solar irradiation, grid development, and land and rooftop availability.

The geospatial analysis combines Vietnam's solar irradiation potential with data on land use and land cover. It also considers factors such as elevation, slope, and proximity to urban centers and protected areas. Four categories of land were identified as suitable for PV development and used in the analysis: (i) agricultural land (annual crops, perennial crops, and other agricultural land), (ii) forest land (timber production), (iii) urban and built-up land (cities, plus land used for power generation or irrigation), and (iv) unused land (barren, range land). The main criteria for available land were that its elevation should be no greater than 2,000 meters, its slope less than 5 degrees, and its population density less than 400 persons per $\mathrm{km}^{2}$. Protected areas are at least $1 \mathrm{~km}$ from the site, and land cover is categorized based on usage. To discount any potential constraints on site, the analysis discounted 75 percent of the identified land. This analysis will require further work with the provinces to properly identify the land best suited for potential solar projects.

The analysis of land availability was then merged with data on solar PV irradiation. ${ }^{5}$ Not only is high solar irradiation a critical determinant of low PPA prices, it tends to occur over arid land that is not ideal for agricultural use.

5. The resulting datasets from the geospatial analysis are provided as an ArcGIS geodatabase and in KMZ format. 


\section{KEY FINDINGS}

\section{Best solar PV irradiation}

The best solar PV irradiation ( $>4.4 \mathrm{kWh} / \mathrm{m}^{2} /$ day) is concentrated in two provinces: Ninh Thuan and Binh Thuan (figure A2.1). Enough land may be available to produce $5 \mathrm{GW}$ of electricity in Ninh Thuan province and 20 GW in Binh Thuan.

The predominant categories of available land in those provinces are unused land and agricultural land. There are four grid substations sized between $220 \mathrm{kV}$ and $500 \mathrm{kV}$. Most of the land is situated within a radius of $20 \mathrm{~km}$ from a substation. There is load demand from both provincial capitals, Phan Thiet and Phan Rang-Thap Cham, and the $500 \mathrm{kV}$ backbone transmission line enables good dispatch management with the rest of the country.

\section{Very good solar PV irradiation}

Vietnam's very good solar PV irradiation $\left(4.2-4.4 \mathrm{kWh} / \mathrm{m}^{2}\right.$ / day) is concentrated in 12 provinces (table A2.1 and figure A2.2), with top potentials of $47 \mathrm{GW}$ in Binh Phuoc, $24 \mathrm{GW}$ in Tay Ninh, 14 GW in Gia Lai, and another 14 GW in Binh Thuan.

The main land cover use is unused land, agricultural land, and production forests. There are 18 substations sized between 220 and $500 \mathrm{kV}$ in these 12 provinces. Most of the land lies within a radius of $20 \mathrm{~km}$ from a substation.

There is load demand in the provincial capitals, while the 500 $\mathrm{kV}$ backbone transmission line enables better dispatch management with the rest of the country.

TABLE A2.1. Provinces and potential installed solar PV capacity (GW): very good potential

\begin{tabular}{|l|c|}
\hline NAME OF PROVINCE & CAPACITY (GW) \\
\hline Binh Phuoc & 47.23 \\
\hline Tay Ninh & 24.22 \\
\hline Gia Lai & 14.65 \\
\hline Binh Thuan & 14.19 \\
\hline Dak Lak & 12.60 \\
\hline Lam Dong & 6.53 \\
\hline Ninh Thuan & 5.52 \\
\hline Khanh Hoa & 3.04 \\
\hline Kon Tum & 2.64 \\
\hline Ba Ria-Vung Tau & 2.16 \\
\hline Dong Nai & 1.50 \\
\hline Binh Duong & 1.27 \\
\hline
\end{tabular}

Source: World Bank.
FIGURE A2.1. Zones with the best solar PV irradiation

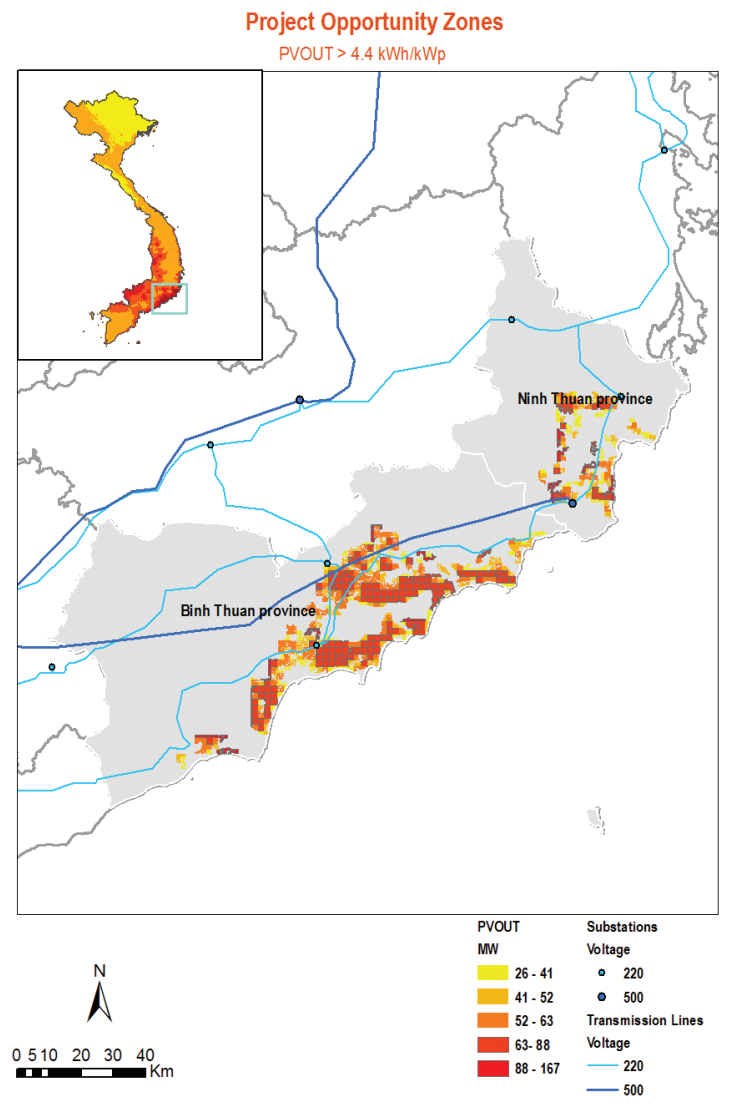

FIGURE A2.2. Zones with very good solar PV irradiation

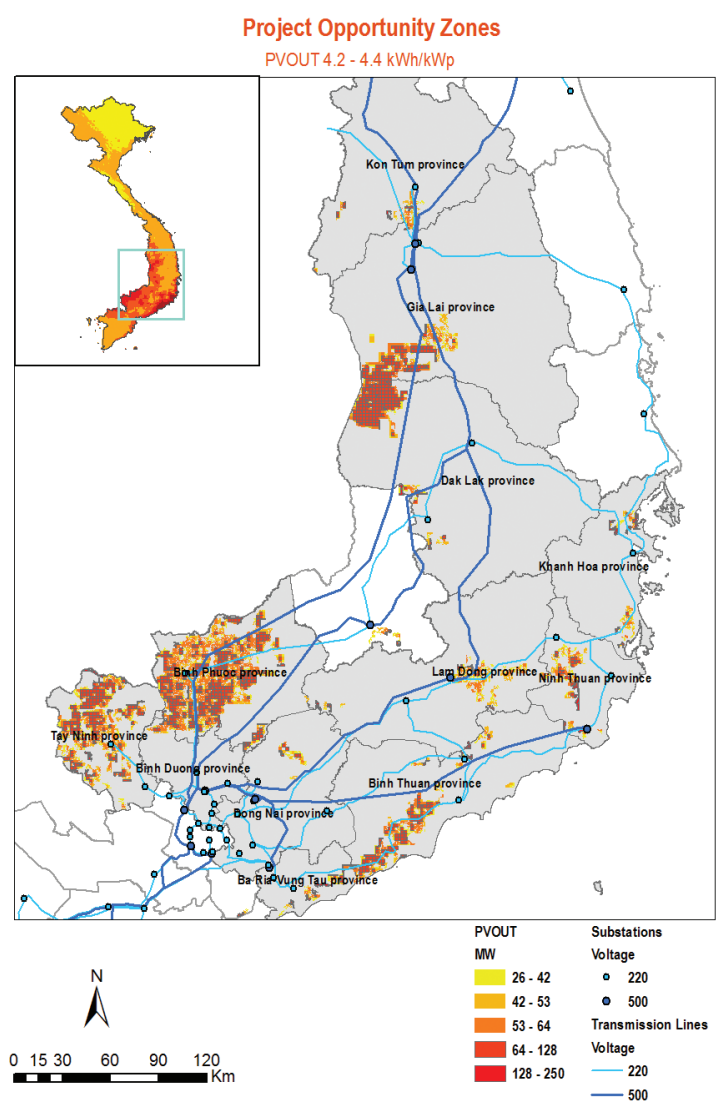


TABLE A2.2. Provinces and potential installed solar PV capacity (GW): good potential

\begin{tabular}{|l|c|}
\hline NAME OF PROVINCE & CAPACITY (GW) \\
\hline Gia Lai & 54.69 \\
\hline Dak Nong & 44.60 \\
\hline Dak Lak & 40.75 \\
\hline Binh Phuoc & 27.80 \\
\hline Dong Nai & 25.05 \\
\hline Binh Duong & 22.81 \\
\hline Long An & 21.06 \\
\hline Lam Dong & 20.22 \\
\hline Kon Tum & 17.66 \\
\hline Binh Thuan & 13.11 \\
\hline Ba Ria-Vung Tau & 7.19 \\
\hline Ben Tre & 6.91 \\
\hline Tra Vinh & 6.34 \\
\hline Khanh Hoa & 5.59 \\
\hline Tay Ninh & 3.65 \\
\hline Tien Giang & 3.17 \\
\hline Soc Trang & 3.02 \\
\hline Ho Chi Minh city & 2.82 \\
\hline Dong Thap & 1.17 \\
\hline Source: & \\
\hline
\end{tabular}

Source: World Bank.

\section{Good solar PV irradiation}

Good solar PV irradiation (4-4.2 kWh $/ \mathrm{m}^{2} /$ day) is found in 19 provinces (table A2.2 and figure A2.3), with the greatest potential in Gia Lai (55GW), Dak Nong (44GW), and Dak Lak (40 GW). Most of the available land falls into the categories of unused land, agricultural land, and production forests. The 19 provinces contain 23 substations sized between 220 and $500 \mathrm{kV}$. Most of the land lies within a radius of $20 \mathrm{~km}$ from a substation.

\section{Floating solar PV}

Floating solar PV (FSPV) is being used increasingly to reduce the need for land (around 1.5 hectares of land are required for $1 \mathrm{MWp}$ of installed capacity in Vietnam) and to facilitate co-location with a hydropower plant and thereby improve dispatch of VRE.
FIGURE A2.3. Zones with good solar PV irradiation

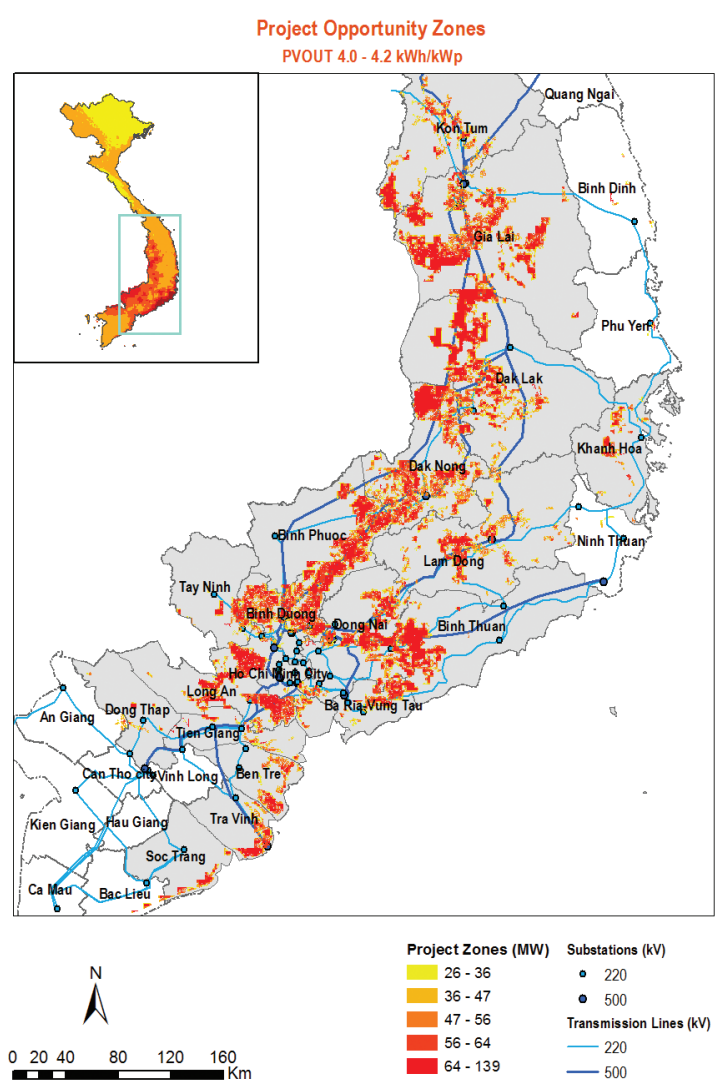

Although the EPC costs of FSPV are currently estimated to be about 10-20 percent higher than ground-mounted plants owing to limited competition in equipment production and the need for expensive anchoring structures, these additional costs are partially offset by a 10-12 percent increase in energy production thanks to the cooling effect and reduction in dust caused by the surrounding water (World Bank Group, ESMAP and SERIS, Where Sun Meets Water: Floating Solar Market Report, 2018). The performance gains are highest in hot climates such as Southeast Asia, where the cooling effect is most important. ${ }^{6}$

Floating PV co-located with hydropower generation has many advantages, such as maximizing the hydro plant's infrastruc-

6. The World Bank's study of Floating PV was published in 2019 under the title Where Sun Meets Water: Floating Solar Market Report. A summary of the report was published in 2018 (with the same title). 
ture and grid connection, minimizing the effects of seasonal variations in power production, supporting daytime peak load, and reserving more hydropower for the evening peak.

Vietnam has nine hydropower dams of a size greater than 100 MW. Two of them, Tri An Lake and Thac Mo, meet the requirements that solar irradiation (expressed in PVout) should be at least $4 \mathrm{kWh} / \mathrm{m}^{2} /$ day and no more than 20 percent of the reservoir should be covered. These two dams have combined a potential of $4.5 \mathrm{GW}$.
FIGURE A2.4. Floating solar PV potential

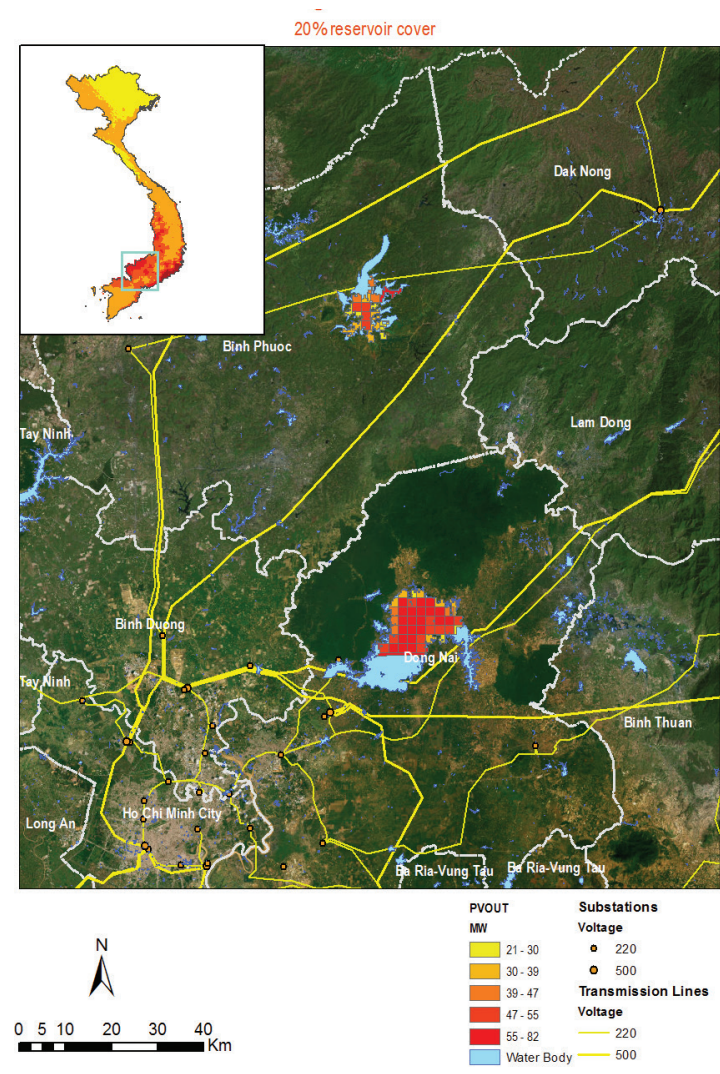




\section{ANNEX 3 \\ SUPPLY CHAIN ANALYSIS}

Annex 3 presents the key results of the Assessment of Vietnam's Solar PV Supply Chain that was commissioned by the World Bank in 2018.

\section{ANALYSIS}

Solar PV is a mature, fast-growing sector based on waferbased crystalline silicon technology. China, Europe, and the United States are the main markets, but 80 percent of modules are manufactured in Asia. In Vietnam, modules are manufactured in collaboration with Chinese and American manufacturers. In 2017, 5 GW of panels were manufactured in Vietnam, representing 7 percent of the global market.

The domestic solar PV market is expected to reach a peak installation rate of around $1.8 \mathrm{GW} /$ year under the targets specified in Revised PDP 7. The country's module-manufacturing capacity, presently dedicated entirely to exports, stands at $5.2 \mathrm{GW} /$ year, about three times the maximum expected size of the local market. Under these conditions, given typical factory sizes, only a limited number of component manufacturers would be able to depend on the local market alone, so the present export orientation will continue to be necessary. But, importantly, charting a clear path to the $12 \mathrm{GW}$ will encourage the creation of EPC companies and other local services in Vietnam to build the planned plants (figure A3.1).

Construction, operations, maintenance, and manufacturing for the local market have the potential to raise Vietnam's GDP by about 0.25 percent by 2030 and to create more than 25,000 jobs.

\section{KEY FINDINGS}

Vietnam's industrial attractiveness. Vietnam's competitiveness in solar PV manufacturing has been assessed on four parameters in order to compare it with selected benchmark countries (China, Malaysia, the Philippines, Thailand, and the United States). The four parameters are (i) production factors (availability and cost of materials, labor force, and capital); (ii) demand factors (local market and exports); (iii) risk and stability factors (country risk, inflation, regulatory framework for renewable energy); and (iv) business support factors (infrastructure, place of industrial sector in economy, innovation and competitiveness).

Vietnam's competitiveness trails that of China, Malaysia, and Thailand in all solar PV industries except for frames and structures. Vietnam's key strengths are in production factors, particularly the labor market, the availability of materials for solar industries (particularly steel), and a favorable cost of energy for industrial consumers. Manufacturing of modules, cells, ingots/wafers, and eventually inverters will be mainly export-driven and will develop independently of local solar PV construction. Structures and services (such as project development, engineering, design, and O\&M) will develop to serve the local market.

Job creation potential. The $12 \mathrm{GW}$ PV target is expected to support as many as 25,000 full-time jobs in project development, services, and O\&M annually in the period through 2030. Solar PV-related employment in Vietnam will derive from (i) development and operation of solar PV power plants, and (ii) manufacturing of equipment. The first category comprises jobs in development, design, construction, and com- 
FIGURE A3.1. Economic activity associated with pursuit of Vietnam's 12 GW solar PV target

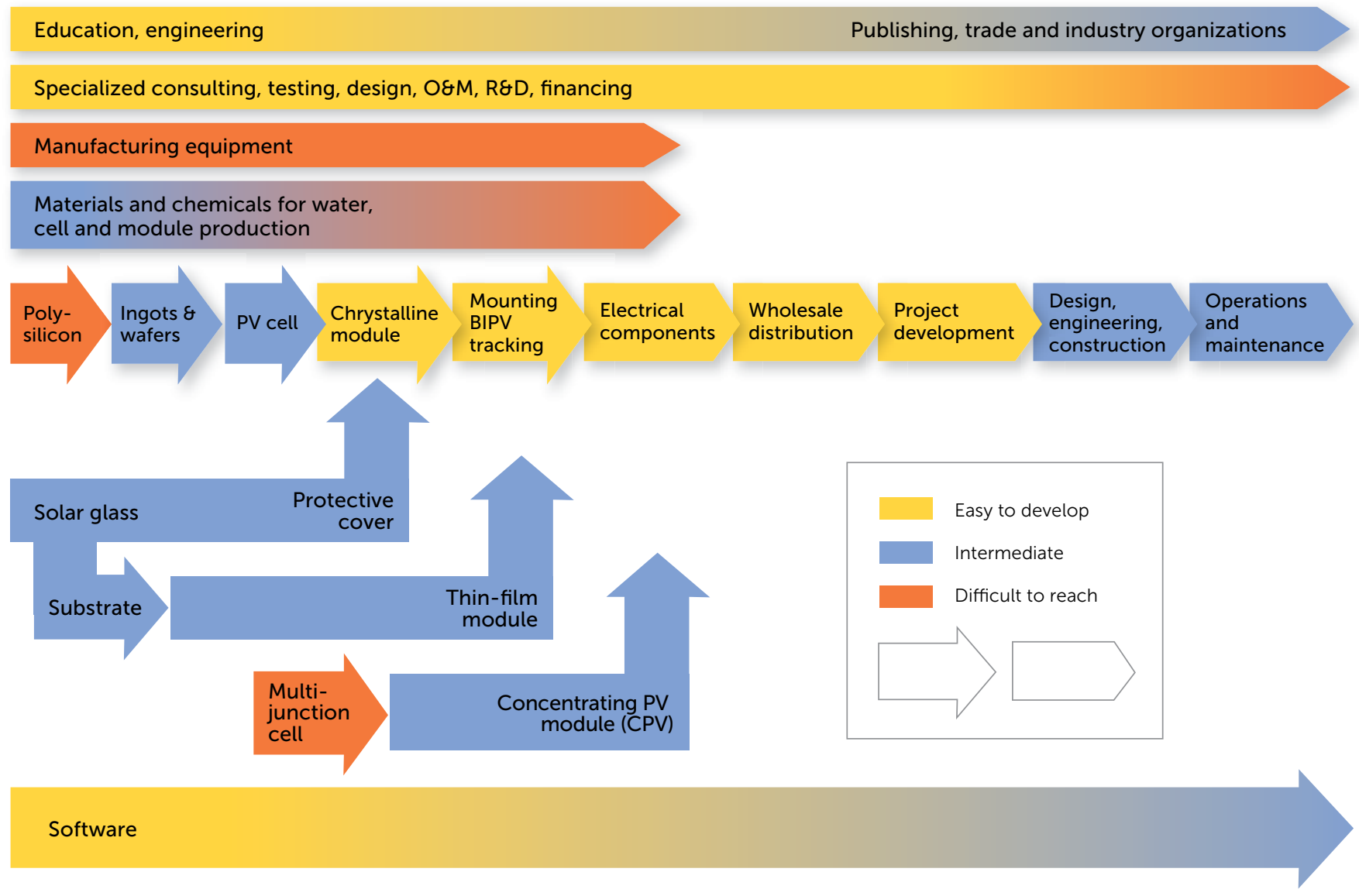

Source: World Bank. 2018. Assessment of Vietnam's Solar PV Supply Chain

missioning of solar PV plants. Jobs created in connection with project implementation tend to be temporary and to disappear once the plant is commissioned and generating power. The implementation phase is followed by operation and maintenance, which extends for the duration of the plant's life cycle.
Job creation in manufacturing is expected to reach nearly 20,000 full-time equivalents by 2030 . Most of these jobs will be export-driven and depend on Vietnam maintaining its current share of the global solar PV market. That, in turn, will depend on the country retaining its attractiveness to international solar PV manufacturers. 


